\author{
UNIVERSIDADE DE SÃO PAULO \\ FACULDADE DE ECONOMIA, ADMINISTRAÇÃO E \\ CONTABILIDADE DE RIBEIRÃO PRETO \\ DEPARTAMENTO DE ECONOMIA
}

RENAN MAKOTO HERCULANO SILVA

ORIENTADORA: PROFA. DRA. ELAINE TOLDO PAZELLO

\begin{abstract}
MICRO E PEQUENAS EMPRESAS FORMAIS AFETAM O
FATO DE SEUS EMPREGADOS SEREM FORMAIS? UM ESTUDO UTILIZANDO O SIMPLES COMO UMA VARIÁVEL INSTRUMENTAL
\end{abstract}

RIBEIRÃO PRETO 
PROFA. DRA. SUELY VILELA

Reitora da Universidade de São Paulo

PROF. DR. RUDINEI TONETO JÚNIOR

Diretor da Faculdade de Economia, Administração e Contabilidade de Ribeirão Preto

PROFA. DRA. MARIA CHRISTINA SIQUEIRA DE SOUZA CAMPOS Chefe de Departamento de Economia 


\section{MICRO E PEQUENAS EMPRESAS FORMAIS AFETAM O FATO DE SEUS EMPREGADOS SEREM FORMAIS? UM ESTUDO UTILIZANDO O SIMPLES COMO UMA VARIÁVEL INSTRUMENTAL.}

Dissertação apresentada ao Departamento de Economia da Faculdade de Economia, Administração e Contabilidade de Ribeirão Preto da Universidade de São Paulo para obtenção do título de Mestre em Economia.

Área de concentração: Economia Aplicada Orientadora: Profa. Dra. Elaine Toldo Pazello 


\section{FICHA CATALOGRÁFICA}

Silva, Renan Makoto Herculano

Micro e pequenas empresas formais afetam o fato de seus empregados serem formais? Um estudo utilizando o SIMPLES como variável instrumental. Ribeirão Preto, 2007.

82 p. : il. ; $30 \mathrm{~cm}$

Dissertação de Mestrado, apresentada à Faculdade de Economia, Administração e Contabilidade de Ribeirão Preto/USP. Área de concentração: Economia Aplicada.

Orientadora: Pazello, Elaine Toldo.

1. Setor informal da economia. 2. Carteira de trabalho assinada. 3. Carga tributária. 


\section{FOLHA DE APROVAÇÃO}

Renan Makoto Herculano Silva

Micro e Pequenas Empresas formais afetam o fato de seus empregados serem formais? um estudo utilizando o SIMPLES como uma variável instrumental.

Dissertação apresentada à Faculdade de Economia, Administração e Contabilidade de Ribeirão Preto da Universidade de São Paulo para obtenção de título de Mestre em Economia.

Área de concentração: Economia Aplicada

Aprovado em:

Banca Examinadora

Profa. Dra. Elaine Toldo Pazello

Instituição: FEARP - USP

Assinatura

Prof. Dr.

Instituição:

Assinatura

Prof. Dr.

Instituição:

Assinatura 
Este trabalho é dedicado aos meus pais, Herculano e Rosa. 


\section{AGRADECIMENTOS}

Meus sinceros agradecimentos

À minha orientadora, prof ${ }^{a}$. Dra. Elaine Toldo Pazello, pela orientação segura, constante incentivo e conduta exemplar, como profissional e ser humano que é. Deixo aqui toda minha estima, consideração e respeito.

Aos prof ${ }^{\circ}$ Dr. Luiz Guilherme Dacar da Silva Scorzafave e Dr. Walter Belluzo Júnior, pelas considerações feitas no exame de qualificação.

Aos demais professores do Departamento de Economia da FEARP/USP, pelos ensinamentos e discussões.

Aos funcionários da FEARP/USP e da Biblioteca Central que, de uma forma ou de outra, contribuíram para o desenvolvimento deste trabalho.

A todos os colegas e amigos do mestrado em Economia Aplicada que compartilharam comigo esses dois anos de curso: Carlos Saiani, Kátia Morinaga, Mazinha, Gedir, Sabrina, Victor, Vagner, Juliana, Carol e aos que não estão mais por lá: Rodrigo e Tadeu. Obrigado pelas oportunidades de aprendizado e convivência.

Aos pós-graduandos de Contábeis e Administração: Flávio, Andrei, Victor, Rafael, Marli, Mara, Lísia, Paulo e Akira pela amizade , colaboração e convivência divertida.

Ao meu irmão, Yudji, por tudo e sempre.

E a todos que contribuíram nessa minha etapa de vida. 


\section{RESUMO}

SILVA, R. M. H. Micro e pequenas empresas formais afetam o fato de seus empregados serem formais? Um estudo utilizando o SIMPLES como uma variável instrumental. 2007. 82f. Dissertação (Mestrado) - Faculdade de Economia, Administração e Contabilidade de Ribeirão Preto, Departamento de Economia, Universidade de São Paulo, Ribeirão Preto, 2007.

Este trabalho estuda a relação entre a formalização das firmas, detentoras de licença municipal ou estadual, e a formalização de seus empregados. Em função da simultaneidade entre os indicadores, utiliza-se o SIMPLES, que representa uma variação exógena na carga tributária relevante para as micro e pequenas empresas, alterando, portanto, os incentivos à formalização para essas firmas. Para avaliar essa relação, o estudo utiliza a base de dados da Economia Informal Urbana (ECINF) de 2003, disponibilizado pelo IBGE em parceria com o SEBRAE, sobre micro e pequenos negócios em áreas não rurais no Brasil. Os resultados indicam que firmas com licença que poderiam aderir ao SIMPLES apresentam um impacto positivo e estatisticamente significante sobre a probabilidade de formalização dos empregados.

Palavras-chave: Setor informal da economia. Carteira de trabalho assinada. Carga tributária 


\begin{abstract}
SILVA, R. M. H. Do formal micro and small enterprises affect the formality of their employees? A study using the SIMPLES as an instrumental variable. 2007. 82p. Dissertation (Master degree) - Faculdade de Economia, Administração e Contabilidade de Ribeirão Preto, Departamento de Economia, Universidade de São Paulo, Ribeirão Preto, 2007.
\end{abstract}

This research studies the relationship between the formality of the enterprises, processing state or municipal license, and the formality of their employees. As result of the simultaneity between the indicators, it is used the Law of the Integrated System of Payment of Taxes and Contributions of the Micro and Small Enterprises (SIMPLES), that represents an exogenous variation on the tax burden that matters to micro and small enterprises. Therefore, modifying the incentives to the formality to these firms.. To analyze this relationship, the study uses the data base for Urban Informal Economy (ECINF) of 2003, available by IBGE in partnership with SEBRAE, about micro and small enterprises in non rural areas in Brazil. The results demonstrate that firms with license that could be benefited by SIMPLES show a positive impact and significant statistically on the probability of formalization of the employees.

Keywords: Informal sector of the economy. Working card. Tax burden 


\section{LISTA DE TABELAS}

Tabela 1 - Proporção de empregados em micro e pequenas empresas, segundo a posse de carteira de trabalho e as grandes regiões (2003)

Tabela 2 - Proporção de empregados em micro e pequenas empresas, segundo a posse de carteira de trabalho e os grupos de atividade (2003).

Tabela 3 - Proporção de empregados com carteira e sem carteira de trabalho, segundo firmas com licença e sem licença (2003)

Tabela 4 - Proporção de empregados, segundo o nível educacional e a posse ou não de carteira de trabalho (2003)

Tabela 5 - Tabulação dos níveis de instrução como porcentagem do grupos de atividades

Tabela 6 - Percentual do número de carteira assinada por número de trabalhadores na firma.

Tabela 7 - Média e desvio - padrão de algumas variáveis utilizadas na análise descritiva.

Tabela $8 \mathrm{a}$ - Probabilidade de ter licença municipal e/ou estadual.

Tabela $8 b$ - Probabilidade de ter carteira de trabalho assinada 


\section{SUMÁRIO}

1 INTRODUÇÃO 10

2 REVISÃO DE LITERATURA 14

2.1 PANORAMA HISTÓRICO DO SETOR INFORMAL E MERCADO DE 14

2.2 SEGMENTAÇÃO (OU DUALIDADE) NO MERCADO DE TRABALHO 17

$\begin{array}{lll}2.3 & \text { RESULTADOS EMPÍRICOS } & 19\end{array}$

CONSEQÜÊNCIAS DA ECONOMIA INFORMAL: EFEITOS DO SETOR
20

2.3.2 CAUSAS DA ECONOMIA INFORMAL 22

LEI DO SISTEMA INTEGRADO DE PAGAMENTO DE IMPOSTOS E

2.4 CONTRIBUIÇÕES DAS MICROEMPRESAS E EMPRESAS DE PEQUENO 26 PORTE (SIMPLES)

3 DADOS, MÉTODOS E PROCEDIMENTOS DE PESQUISA 29

$\begin{array}{lll}3.1 & \text { CONDUÇÃO DO ESTUDO } & 29\end{array}$

3.2 PROCEDIMENTOS E INSTRUMENTOS DE PESQUISA 30

3.2.1 MOTIVAÇÃO PARA USO DE VARIÁVEIS INSTRUMENTAIS (VI) 34

4 ANÁLISE DESCRITIVA RESULTADOS ESTIMADOS

4.1 ANÁLISE DESCRITIVA $\quad 42$

$\begin{array}{lll}4.2 & \text { RESULTADOS } & 57\end{array}$

5 CONSIDERAÇÕES FINAIS

REFERÊNCIAS BIBLIOGRÁFICAS 73

$\begin{array}{ll}\text { APÊNDICE } & 77\end{array}$ 


\section{INTRODUÇÃO}

No Brasil, emprego formal, geralmente, implica que o trabalhador seja um empregado com carteira de trabalho assinada. Isso qualifica o empregado para seguridade social e proteção sob legislação do trabalho. Com relação ao emprego informal no Brasil, entende-se que o trabalhador é um empregado, mas sem carteira assinada, o que significa que a relação trabalhista não é registrada no Ministério do Trabalho (NERI, 2002).

O regulamento do mercado de trabalho no Brasil foi aprovado no Código de Trabalho de 1943. Um contrato de trabalho registrado, representado pela carteira de trabalho assinada, confere um direito de posse legal para uma série de termos contratuais, tais como compensação em caso de uma demissão não justificada, licença maternidade, entre outros. Diante dessas obrigações, pode haver um forte desincentivo para empregadores registrarem esses contratos (HENLEY; ARABSHEIBANI; CARNEIRO, 2006).

O conceito de setor informal surgiu nos anos 1970, como tentativa de explicar um fenômeno mais antigo, relacionado à pobreza, reprodução de atividades de baixa produtividade e trabalho sob condições de precariedade à margem do quadro legal, principalmente em países mais pobres (THEODORO, 2002). É a partir de trabalhos seminais como, por exemplo Hart (1973), que trouxe à tona o fenômeno de setor informal, a partir de um estudo dos países subdesenvolvidos, que vários outros estudos surgiram apresentando preocupação com esse fenômeno que passou a receber várias denominações. Dentre a miríade de terminologias, é possível encontrar, além de economia informal: economia subdesenvolvida (underground economy), subterrânea (subterranean), sombria (shadown), oculta (hidden), paralela (parallel), clandestina (clandestine), secundária (second) ou doméstica (household) (GËRXHANI,1999, p.3). 
Pode-se olhar para a informalidade também sob a ótica das firmas e nesse sentido também há diversas diferenças entre firmas formais e informais. De Paula e Scheinkman (2006) apresentam algumas dessas diferenças, examinando dados da pesquisa de economia informal (ECINF) do IBGE que cobre uma amostra de pequenas firmas de até 5 empregados:

(i) uma firma formal possui maior número de empregados que uma informal;

(ii) uma firma formal investe mais por trabalhador;

(iii) quando uma firma vende ou compra de empresas formais, ela tem mais probabilidade de se tornar formal, assim como aumenta essa probabilidade à medida que vende mais a grandes empresas.

As micro e pequenas empresas (MPEs) são, por natureza, locais de trabalho que concentram grande parte dos trabalhadores informais. Porém, embora correlacionados, a formalidade da firma e a formalidade do trabalhador são fenômenos diferentes. Para a formalidade da empresa vários indicadores podem ser usados, como por exemplo, posse de licença municipal ou estadual, posse de CNPJ, entre outras. Esse trabalho tem por objetivo olhar para essa relação entre o indicador de formalidade do trabalhador e o indicador de formalidade da firma, especificamente estimar a importância da formalidade da empresa sobre a do trabalhador. O problema nesta estimação está justamente na endogeneidade presente nessa relação. O trabalhador que valoriza as leis deve procurar uma firma formalizada para trabalhar, da mesma forma que firmas formalizadas devem ter preferências por trabalhadores com essas características no momento da contratação. De uma forma mais geral, os melhores trabalhadores em termos de características produtivas, muitas vezes, não observáveis, devem trabalhar em firmas formalizadas, as quais, por sua vez, também devem oferecer melhores condições de trabalho.

Essas micro e pequenas empresas, ao decidirem escolher o setor formal ou não para atuarem em suas atividades, apresentam custos e benefícios. Como benefício de não passar ao 
setor formal, há a onerosa carga tributária que deixa de ser paga. Como custo da informalidade, há o enforcement da regulação, entendida como inspeções de fiscais do trabalho, que contribui ao combate à informalidade, podendo até ter maior importância que uma redução na carga tributária (ALMEIDA; CARNEIRO, 2005).

Ulyssea (2005b, p.1) constata que

\begin{abstract}
Ainda que a fiscalização por parte do Estado não seja efetiva a ponto de tornar proibitiva a atividade e a contratação ilegal de mão-de-obra, essas penalidades representam um peso considerável para as firmas, especialmente no caso dos pequenos empreendimentos [...] muitas vezes as firmas são obrigadas a pagar propinas aos agentes de fiscalização para poderem continuar a exercer suas atividades ou simplesmente decidem mantê-las em uma escala reduzida para evitar a fiscalização governamental.
\end{abstract}

Mas, se de fato, a elevada carga tributária é um elemento que incentiva a informalidade, uma medida econômica que reduza a carga tributária e desburocratize os procedimentos para pagá-las, favorecendo as micro e pequenas empresas, deve levar a um aumento na formalização dessas empresas. Este é o objetivo da Lei do Sistema Integrado de Pagamento de Impostos e Contribuições das Microempresas e Empresas de Pequeno Porte, conhecida como SIMPLES, instituída pela Lei nº317, de 5 de dezembro de 1996. Para esse trabalho, o SIMPLES representa uma variação exógena na carga tributária que deve impactar na formalização das empresas. Essa variação exógena na carga tributária é o que vai nos permitir estimar o impacto da formalização da empresa na formalização do trabalhador.

Monteiro (2004) mostra, em trabalho pioneiro sobre impacto do SIMPLES na formalização das empresas, que a legislação do SIMPLES aumentou a probabilidade das micro e pequenas empresas se regularizarem. Ou seja, o trabalho de Monteiro fornece - nos um primeiro indício da plausibilidade do nosso instrumento.

Em suma, o objetivo do presente trabalho é: 
- Verificar, através de testes econométricos, se o fato das empresas serem formais, ou seja, possuírem licença municipal e / ou estadual afeta positivamente a probabilidade de seus empregados terem carteira de trabalho assinada ou não assinada.

Esse trabalho contribui com a literatura porque, pelo que temos conhecimento, tal relação ainda não foi estimada para o Brasil. Reconhecer essa relação é importante, pois possibilitará ao policy maker prever como políticas que afetem a formalização das empresas, afetarão a formalização dos trabalhadores.

Com essa finalidade, o trabalho está dividido em 4 partes, além desta introdução. A seção 2 contém uma revisão da literatura sobre o setor informal da economia e o mercado de trabalho informal, além de detalhar a Lei do SIMPLES. A seção 3 dispõe os dados, métodos e procedimentos de pesquisa utilizados. A seção 4 analisa as estatísticas e descreve os principais resultados obtidos, em relação aos fatores que influenciam a economia informal do país. A última parte do trabalho é dedicada a considerações finais da análise. 


\section{REVISÃO DE LITERATURA}

Neste capítulo, é feita uma revisão bibliográfica sobre o tema setor informal no mundo e no Brasil, procurando abordar suas principais causas e conseqüências e alguns trabalhos que já tiveram algumas evidências empíricas sobre esse tema. É apresentada também uma idéia sobre a segmentação no mercado de trabalho. Por fim, faz-se uma apresentação da lei do Sistema Integrado de Pagamento de Impostos e Contribuições das Microempresas e Empresas de Pequeno Porte (SIMPLES).

\subsection{PANORAMA HISTÓRICO DO SETOR INFORMAL E MERCADO DE TRABALHO INFORMAL}

A denominação Mercado de Trabalho Informal foi empregada pela primeira vez por Hart em estudo sobre Ghana. Contudo, a denominação Setor Informal foi rapidamente generalizada em estudos da Organização Internacional do Trabalho (OIT) a partir da década de 1970, passando depois para a literatura acadêmica (CACCIAMALI, 1983).

Ainda que o fenômeno do setor informal tenha recebido mais atenção a partir da década de 1970, o pequeno comércio de rua e comerciantes em condições precárias já estavam presentes nas ruas de Nova Iorque ou mesmo Paris na virada do século XIX para XX, concentrando atividades econômicas que, há muito tempo, já expressava o que hoje descrevese como atividade informal: “A incidência de fenômenos como a pobreza, a reprodução de atividades de baixa produtividade, o exercício do trabalho sob condições de extrema 
precariedade, à margem mesmo do aparato legal vigente, antecede a idéia de setor informal" (THEODORO, 2002, p.8).

Para os países da América Latina, o início da 'informalidade' tem sido atrelado ao processo de industrialização. Essa idéia coloca que as políticas de industrialização por substituição de importações, adotadas entre 1950-70, conduziram à concentração da indústria em uma ou duas cidades nos países desse continente. Isso fez com que, aliada à falta de perspectiva no meio rural, a industrialização tenha incentivado uma migração massiva do meio rural para o meio urbano, promovendo uma expressiva concentração urbana que contribuiu para o emprego informal, uma vez que o número de empregos regularizados nas cidades não eram suficientes (DEDECCA; BALTAR, 1997).

A concepção de setor informal está vinculada à visão sobre desenvolvimento econômico e mercado de trabalho na América Latina que se tornou dominante no pós-guerra. Considerava-se que o desenvolvimento econômico, entendido como modernização socioeconômica alavancada pela industrialização regional, promoveria homogeneização das condições socioeconômicas nos países da região. A trajetória da industrialização consolidou um núcleo de atividades econômicas dominado pela grande empresa nacional e estrangeira, mas sua participação no emprego e no valor agregado da economia sempre foi restrita. A importância dos pequenos empreendimentos na estrutura da economia sinalizava os limites da transformação produtiva na região da América Latina, contrastando com a esperada tendência de homogeneização da estrutura ocupacional (tanto das formas de trabalho quanto do padrão de remuneração) que não se consolidou (DEDECCA; BALTAR, 1997, p.66).

Um autor que tem estudado esse processo de informalização nas relações de trabalho é Ramos que constata que no Brasil cresceu a importância do mercado de trabalho informal nos últimos anos em função do grande crescimento desse estrato. Ramos (2002), usando dados da Pesquisa Mensal de Emprego (PME) do IBGE, analisa a relação entre composição setorial do 
emprego (sintetizados pela indústria de transformação e o segmento de serviços) e informalidade ao longo da década de 1990. Com a abertura da economia, no início da década de 1990, as firmas brasileiras viram-se obrigadas a adotar uma nova postura que exigiu enxugamento da estrutura produtiva, sobretudo na indústria de transformação, com o objetivo de produzir produtos mais competitivos, dado o aumento da competitividade estrangeira no país. A busca pelo aumento da produtividade era necessária, reforçada pela implantação do Plano Real, principalmente em sua primeira fase, que gerou apreciação da moeda, tornando mais fácil importar produtos. Para atingir esse fim (aumento da produtividade) uma das práticas mais adotadas, que contribuiu para o crescimento do setor de serviços, foi a “terceirização".

Conforme Ramos (2002), o resultado é que, entre 1991-2001, o setor de serviços (que possui grau de informalidade tradicionalmente elevado) acusou expansão, ao passo que a indústria de transformação (caracterizada por vínculos trabalhistas mais formalizados do que o setor de serviços) retraiu-se, pois foi mais afetada por este processo. A saída foi buscar tecnologias mais modernas, que empregassem um número menor de pessoas e com grau mais elevado de qualificação. Os desempregados da indústria, por sua vez, terminaram direcionados para o setor de serviços, como o comércio, em que a informalidade é maior. $\mathrm{O}$ efeito geral deste fenômeno foi o de ampliar o grau de informalidade da economia brasileira. Cardoso Jr e Fernandes (2000, p.46) colocam ainda que nesse cenário de abertura econômica o segmento terciário (comércio e serviços pessoais, por exemplo) passa a funcionar como colchão absorvedor do excedente estrutural de mão-de-obra.

Tradicionalmente, o setor informal possui estreita relação com a pobreza. De acordo com informações de Fernandes, Pazello e Felício (2002) - utilizando dados da Pesquisa Nacional por Amostra de Domicílio (PNAD) de 1999, disponibilizados pelo IBGE - a maior parte dos pobres, maiores de dezessete anos, encontra-se no mercado de trabalho, ou seja, é 
ativa $(63,02 \%)$ como também são ocupados $(80,5 \%)$. Dentro deste universo da população ocupada, a distribuição por setor indica que, dos trabalhadores que vivem em famílias com renda familiar per capita inferior à linha de pobreza (isto é, trabalhadores pobres) a maior

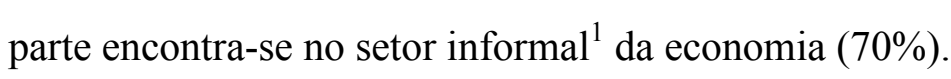

Um outro ponto que desperta interesse é que cláusulas da legislação relativas a salário - mínimo, jornada-padrão de trabalho e práticas diversas de pagamentos no setor informal do mercado de trabalho brasileiro "é surpreendentemente alta, comparável à observada no segmento legal" de modo que "a informalidade empregatícia no Brasil é principalmente um fenômeno fiscal e não à recusa das firmas em honrar direitos trabalhistas legalmente estabelecidos" (NERI, 2000).

\subsection{SEGMENTAÇÃO (OU DUALIDADE) NO MERCADO DE TRABALHO}

O ponto de vista comum entre escolas que estudam o fenômeno do setor informal na América Latina é basicamente sobre a sua emergência, que decorreu da acelerada migração rural-urbana e o excedente de oferta de trabalho que isso criou nas cidades (PORTES; SCHAUFFLER,1993).

Os estudos sobre dualismo econômico multiplicaram-se a partir do trabalho de Lewis, em 1953, que destacou-se por fornecer informações consistentes em relação à dicotomia urbano-rural, dualismo este que está relacionado às diferenças em aspectos da produção e tecnologia das atividades desenvolvidas (ou seja, o dualismo urbano-rural não está relacionado ao lugar onde a atividade é situada). Ainda que essa dicotomia algumas vezes

\footnotetext{
${ }^{1}$ Informal neste caso inclui empregados sem carteira de trabalho assinada e trabalhadores por conta - própria.
} 
conste como distinção entre o tradicional e moderno, é geralmente mais conhecida como dualismo entre os setores formal e informal (ESFAHANI; SALEHI-ISFAHANI, 1989, p.818).

Uma das idéias centrais sobre mercados segmentados é que segmentos diferentes do mercado de trabalho apresentam regras operacionais diferentes. De um lado, o segmento formal é visto como detentor de boas condições de trabalho, do outro, o segmento informal é visto como possuidor de más condições de trabalho. Outro ponto importante, em relação ao mercado de trabalho segmentado, é que postos de trabalho do setor formal são racionados de modo que apenas uma parcela de trabalhadores produtivamente homogêneos e desejosos de obter um emprego no setor formal conseguiriam sucesso. A idéia de segmentação, desse modo, é que o mecanismo de mercado falharia em equalizar a situação desses trabalhadores, porque trabalhadores iguais, em termos de preferências e produtividade, obtêm níveis de utilidade distintos ao ocuparem postos de trabalho distintos (FERNANDES, 2002).

Não obstante ao que foi mencionado, atualmente, a moderna literatura sobre mercado de trabalho informal sugere que se deve olhar para os setores formal e informal de um modo integrado, ou seja, o oposto da visão de mercado de trabalho segmentado, destacando o papel do setor informal como uma fonte de trabalho não regulamentado para firmas (ALMEIDA; CARNEIRO, 2005). Maloney (2004), por exemplo, ao analisar evidências recentes sobre informalidade na América Latina, adota uma visão do setor informal nesses países em desenvolvimento primariamente como um setor microempresarial não regulado, e não como um resíduo de mercado de trabalho segmentado. Em sua resenha sobre informalidade, ULYSSEA (2005a, p.12) enfatiza a preocupação dos trabalhos recentes em analisar as diferentes características pertinentes à informalidade de maneira mais integrada. Em particular, segundo o autor, os trabalhos tratam das interações entre aspectos institucionais 
relativos à informalidade no mercado de trabalho e as escolhas setoriais entre firmas e trabalhadores.

\subsection{RESULTADOS EMPÍRICOS}

Obter estatísticas exatas sobre alocação de recursos de países na economia informal é importante para permitir decisões de política econômica, uma vez que atividades econômicas informais é um fato da vida no mundo (SCHNEIDER; ENSTE, 2000).

Estima-se que a produção informal global é igual a aproximadamente US\$9 trilhões e é largamente afetada pela política tributária (The Economist, 1999 apud IHRIG; MOE, 2001, p.369).

O tamanho, causas e conseqüências da economia das sombras variam por diferentes tipos de países, mas algumas comparações podem ser úteis. Entre os motivos mais importantes para que policy makers se preocupem com o crescimento da economia das sombras, dois têm destaque:

(i) Um crescimento da economia informal pode ser visto como a reação de indivíduos que se sentem sobrecarregados pelo Estado;

(ii) Indicadores oficiais sobre desemprego, força de trabalho, renda, consumo, tornam-se não confiáveis. Política baseada em indicadores oficiais errôneos são provavelmente ineficazes ou piores.

Por um lado, uma próspera economia informal pode atrair trabalhadores domésticos e estrangeiros de economias oficiais e criam competição para firmas oficiais. Por outro lado, em torno de $66 \%$ da renda ganha na economia informal é imediatamente gasta no setor oficial, 
então tem um efeito positivo sobre o crescimento econômico e, conseqüentemente, para a receita e impostos indiretos (SCHNEIDER; ENSTE, 2000).

\subsubsection{CONSEQUENCIAS DA ECONOMIA INFORMAL: EFEITOS DO SETOR INFORMAL SOBRE CRESCIMENTO ECONÔMICO}

Em relação ao impacto da economia informal sobre o setor formal, há considerável desacordo com o papel do setor informal no processo de crescimento ecônomico. Esta questão é parte de uma questão maior que intriga economistas e policy makers: "Por que algumas nações tornam-se ricas, enquanto outras permanecem pobres?” (ASEA, 1996, p.163).

Loayza (1996) questiona a relação entre tamanho do setor informal e crescimento econômico. O autor conclui que nas economias onde a carga tributaria estatutária (por estatuto) é maior que ótima e onde o sistema de enforcement é muito fraco, o tamanho relativo do setor informal é negativamente correlacionado com a taxa de crescimento econômico. Isto quer dizer que mudanças em parâmetros políticos e qualidade das instituições governamentais, que promovam um aumento no tamanho relativo da economia informal, irão gerar uma redução na taxa de crescimento econômico. E, tradicionalmente, muitos países da América Latina possuem regulações excessivas e fracas instituições governamentais. (LOAYZA, 1996).

Em outro estudo, que usa uma amostra de países industriais e em desenvolvimento, examina-se empiricamente o efeito total da regulação fiscal dos negócios sobre o crescimento econômico e sobre o tamanho relativo do setor informal. Mostra-se que a melhor resposta para uma economia saudável é uma firma que se reestrutura, com flexibilidade para 
administrar choques negativos e conseguir vantagens de oportunidades de crescimento. A informalidade é a segunda melhor porque envolve perda, ao menos parcialmente, de vantagens da legalidade, como proteção política e judicial, acesso a instituições de crédito formal, e participações em mercados internacionais (LOAYZA; OVIEDO; SERVÉN, 2005).

Além disso, tentar escapar do controle do Estado força muitas firmas informais permanecerem sub-otimamente pequenas para mascarar suas atividades. Além disso, o setor informal pode gerar uma externalidade negativa: por evitar tributos, atividades informais usam e congestionam a infra-estrutura pública sem ajudar a repô-la. Logo, um setor informal maior afeta negativamente crescimento econômico (LOAYZA; OVIEDO; SERVÉN, 2005, LOAYZA, 1996).

Por outro lado, essa afirmação, de que o tamanho do setor informal é negativamente relacionada com a taxa de crescimento, ignora a extensão de que o setor informal pode contribuir para a criação de mercado, aumento de recursos financeiros, aumento do empreendedorismo e transformação de instituições econômicos, sociais e legais necessárias para acumulação. A economia informal pode ainda levar a uma maior competitividade empresarial, proporcionando maior eficiência para firmas e limites às atividades governamentais, por meio da ampliação da demanda por serviços urbanos e produção de pequena escala (ASEA, 1996, p. 165).

Existe um desacordo na literatura se países deveriam ou não agir para reduzir o tamanho do setor informal. Os que defendem que o setor informal é importante argumentam que a informalidade fornece um meio relativamente fácil de criar e expandir emprego. Este setor pode tornar-se uma fonte de subsistência durante recessões. Mesmo se a eliminação do setor informal for a decisão tomada, os custos de incrementar cada enforcement podem exceder os benefícios (IHRIG; MOE, 2001). 
Na perspectiva de que o setor informal pode expandir emprego, uma das formas pelas quais isso ocorre é através da subcontratação. Um dos maiores benefícios do setor formal em subcontratar é não ter que ser responsável pelas condições de trabalho no setor informal urbano (salário-mínimo, seguridade social ou outros benefícios). Além disso, trabalhando com uma força de trabalho relativamente pequena, variações na demanda do mercado podem, entretanto, ser rapidamente respondidas por aumento ou diminuição na subcontratação. Além disso, subcontratação também pode oferecer oportunidade de expandir acesso ao mercado para microempresas (THOMAS, 2002).

\subsubsection{CAUSAS DA ECONOMIA INFORMAL}

Muitas causas são apontadas por autores como influências positivas para atividades informais. Um deles, apoiado no resultado de seu modelo estimado - modelo estrutural de múltiplas causas e múltiplos indicadores (MIMIC) - mostra que a regulamentação da economia, proxy do grau de abertura econômica do país, apresenta pequena influência positiva $(2,12 \%)$ sobre a economia submersa, ao passo que as variáveis que mais afetaram a economia submersa foram a taxa de desemprego (relação positiva de 20,41\%) e renda disponível (relação negativa de 24,56\%), sugerindo que alta carga tributária incrementa a atividade submersa. Portanto, carga tributária, grau de regulamentação da economia e taxa de desemprego são fortes determinantes da atividade submersa brasileira, que aumenta no período analisado de pós-estabilização da inflação brasileira, entre 1994-1999 (RIBEIRO; BUGARIN, 2003). 
De acordo com Lemieux, Fortin e Fréchette (1994), tributação e seus efeitos sobre incentivos ao trabalho é uma questão central em política pública. Usando microdados de uma pesquisa realizada na área metropolitana de Quebec (Canadá) para analisar empiricamente decisões de oferta de trabalho numa economia underground (ou setor informal, não tributado da economia) esses autores mostram que impostos afetam não apenas escolhas trabalho-lazer, mas, também, estimulam atividades do mercado de trabalho no setor informal. Os resultados indicam que impostos distorcem atividades no mercado de trabalho entre um setor regular para o setor informal, mas a distorção é pequena para o trabalhador médio, ou seja, para um trabalhador médio, que é improvável trabalhar no setor underground, o tributo e o sistema de transferência não distorcem significantemente a alocação de horas de trabalho do setor regular para o informal.

Encontrou-se que atividades do mercado de trabalho na economia informal são concentrados entre pessoas da cauda inferior da distribuição de renda. Atribuiu-se esse achado ao fato de que ganhos do trabalho no setor informal são uma função côncava das horas de trabalho. Essas distorções podem ser importantes para alguns grupos específicos da população, como por exemplo, os reivindicadores de bem-estar social, que são mais propensos a trabalhar no setor informal (LEMIEUX, FORTIN; FRÉCHETTE, 1994).

Aumento da competição estrangeira em países em desenvolvimento é também freqüentemente alegado como causa que leva à expansão do setor informal. Usando dados do Brasil e Colômbia, que experimentaram grandes reduções de barreiras comerciais nas décadas de 1980 e 1990, não se encontrou evidência significativa de que reformas comerciais contribuíram para aumentar o emprego informal no Brasil. Os resultados sugerem que, comparado à rigidez do mercado de trabalho, política comercial é de importância secundária em determinar a incidência do emprego informal (GOLDBERG; PAVCNIK, 2003). Mesmo 
que a completa absorção da força de trabalho no setor formal seja desejável, ela não ocorrerá sem relaxar regras rígidas do trabalho (PORTES; SCHAUFFLER, 1993).

Igualmente desejável é a transformação de atividades de subsistência dentro da dinâmica de pequenas firmas autônomas, mas não ocorrerá através de simples remoção dos controles estatais sem programas de apoio a pequenas empresas em desenvolvimento (PORTES; SCHAUFFLER, 1993).

A literatura sobre economia informal freqüentemente atribui à tributação um importante determinante para a existência da economia informal. Uma vez que os indivíduos acreditam que o governo possui capacidade para converter a receita oriunda dos tributos para incrementar os bens públicos, dentro de um consolidado ambiente institucional, os benefícios de pertencer ao setor formal podem superar os benefícios (em termos de não pagamento de impostos) de transitar para o setor informal da economia. Entretanto, se o Estado é considerado como expressão de burocracia e corrupção, indivíduos se sentem impelidos a aderir ao setor informal (FRIEDMAN et al., 2000).

Loayza (1996) apresenta um modelo de crescimento endógeno macroeconômico que trata o setor informal como uma variável não observada, a ser estimada pelo modelo. Esse modelo estatístico considera o tamanho relativo do setor (produção informal como total da produção) como variável latente que potencialmente tem múltiplas causas e múltiplos indicadores. O autor estima o setor informal em 40 países da América Latina e encontra algumas evidências em relação a três correlações estatísticas significantes a $10 \%$ de nível de confiança. Carga tributária $(0,33)$ e restrições no mercado de trabalho $(0,49)$ afetam o tamanho relativo do setor informal positivamente, enquanto rigidez e eficiência das instituições governamentais $(0,42)$ levam ao decréscimo o setor informal.

Em outro trabalho, Loayza, Oviedo e Servén (2005) estudam os efeitos da regulação no crescimento econômico e no tamanho relativo do setor informal, tendo como base uma 
amostra de países industriais e em desenvolvimento. Conclui-se que a pesada carga tributaria - particularmente em produtos e mercado de trabalho - reduz o crescimento e induz informalidade (LOAYZA; OVIEDO; SERVÉN, 2005). A carga tributária, ao lado do grau de regulamentação da economia e da taxa de desemprego (RIBEIRO; BUGARIN, 2003) ou ao lado do alto quadro regulatório e de corrupção (JOHNSON; KAUFMANN; ZOIDOLOBATÓN, 1998) agiriam como fortes determinantes do aumento do setor informal da economia.

Nesse cenário, um ciclo vicioso pode emergir, explicando a informalidade no Brasil, ao menos em parte: altos tributos induzem empresas a operarem na informalidade, propiciando, tudo o mais constante, uma carga tributária mais onerosa sobre os empreendimentos formais que sobram (FARREL, 2004).

Como pode ser visto pelos autores desse tópico citados acima, tributos e burocracia são comumente relacionados a fatores que incitam agentes a preferirem pertencer ao setor informal. Nesse sentido, a influência de políticas focadas em aumentar motivações individuais para permanecer no setor regular da economia provavelmente geram uma renda de equilíbrio maior do que uma abordagem de intimidação que diminua a motivação individual de operar na economia irregular (FUGAZA; JACQUES, 2002, p.415).

Tentar caracterizar o setor informal de um país por meio de microdados que representam um corte transversal de unidades econômicas também é uma forma de investigar causas do setor informal. Com base em informações de 44711 pequenas firmas disponíveis na Pesquisa de Economia Informal Urbana (ECINF) da edição de 1997, De Paula e Scheinkman (2006) investigam os determinantes da atividade econômica informal. Eles apresentam e testam com modelo probit as implicações de determinantes da informalidade (definida como evasão de tributos) utilizando como variáveis dependentes dummies que são proxies de formalidade. Os autores encontram que firmas informais revelam-se menores, menos 
produtivas e com menos capital por trabalhador. Além disso, mostra-se que na aplicação do valor adicionado tributado para cada venda e para cada receita do estabelecimento econômico, recebe-se em contrapartida um crédito pela importância de tributo pago em estágios anteriores da cadeia produtiva. Esse crédito será usado para quitar responsabilidades para com autoridades tributárias. Como compras de vendedores informais não são aceitos para créditos tributáveis, as vendas para instituições governamentais, firmas grandes e pequenas, tendem a aumentar a probabilidade de formalização, sendo o maior efeito associado às vendas para organizações governamentais e o menor efeito para pequenas firmas. Os autores interpretam esses resultados como sugestão de que existe efeito em cadeia sobre a formalização (DE PAULA; SCHEINKMAN, 2006, p.23).

\subsection{LEI DO SISTEMA INTEGRADO DE PAGAMENTO DE IMPOSTOS E CONTRIBUIÇÕES DAS MICROEMPRESAS E EMPRESAS DE PEQUENO PORTE (SIMPLES)}

No final dos anos 1990, foi adotada no país uma legislação tributária que simplificou e reduziu a carga tributária sobre as microempresas e empresas de pequeno porte. No Brasil, a Lei $n^{\circ}$ 9317/96, denominada Lei do "SIMPLES", tem permitido aos pesquisadores avaliar o impacto da tributação sobre a formalidade das empresas. Antes de continuarmos é importante descrever a Lei. O SIMPLES é uma lei que foi sancionada em dezembro de 1996 e que estabelece o tratamento diferenciado, simplificado e favorecido no recolhimento de impostos federais para as micro e pequenas empresas (BRASIL, 1996). A inscrição do SIMPLES implica o pagamento mensal unificado de seis impostos e contribuições federais: Imposto de 
Renda das Pessoas Jurídicas (IRPJ), Contribuição para os Programas de Integração Social e de Formação do Patrimônio do Servidor Público (PIS/PASEP), Contribuição Social sobre o Lucro Líquido (CSLL), Contribuição para Financiamento da Seguridade Social (COFINS), Imposto sobre Produtos Industrializados (IPI) e Contribuição para Seguridade Social do proprietário da firma. Esse tributo simplificado depende da receita bruta acumulada no ano calendário e varia de $3 \%$ a $5 \%$ do total da receita bruta para microempresas e de $5,4 \%$ a $8,6 \%$ para pequenas empresas

Ainda de acordo com a Secretaria da Receita Federal, o SIMPLES, que está em vigor desde 1/1/1997, permite que a pessoa jurídica inscrita dentro dessa lei fique dispensada do “pagamento das contribuições instituídas pela União como as destinadas ao SESC, ao SESI, ao SENAI, ao SENAC, ao SEBRAE, e seus congêneres, bem como as relativas ao salárioeducação e à Contribuição Sindical Patronal”. Acrescente-se a isso que o SIMPLES permite também "incluir o ICMS e/ou o ISS devido por microempresa e/ou empresa de pequeno porte, desde que o Estado e/ou o município em que esteja estabelecida venha aderir ao SIMPLES mediante convênio". Isso significa que o SIMPLES, que é um imposto federal, poderá incluir o ICMS ou ISS, respectivamente um imposto estadual e municipal, desde que o Estado ou município em que esteja estabelecida a empresa venha a ele aderir mediante convênio ${ }^{[}$.

A legislação não abrange todas as atividades econômicas, seja porque o empreendimento está listado como atividade de natureza vetada pela lei, ou seja porque a

\footnotetext{
${ }^{2}$ Pela legislação 9.317/96, a definição de micro e pequena empresa é baseada em receita anual. Microempresas são firmas licenciadas com receita anual igual ou menor que R \$ 120 mil, enquanto pequena firma possui receita anual superior a $\mathrm{R} \$ 120$ mil e inferior a $\mathrm{R} \$ 1,2$ milhão.

${ }^{3}$ Caso o Estado estabeleça convênio com o sistema previsto na Lei no 9316/96, é possível que o SIMPLES inclua o ICMS. Um outro ponto refere-se ao SIMPLES paulista (Lei $\left.\mathrm{n}^{\circ} 10086 / 98\right)$, regulamentada pelo Decreto $\mathrm{n}^{\circ}$ 43738/98, que está fora do escopo deste trabalho, que analisa apenas o SIMPLES federal. De acordo com o SEBRAE-SP, como o Estado de São Paulo não estabeleceu esse convênio, criou o SIMPLES paulista, que é um "regime tributário simplificado e favorecido que o governo paulista criou para beneficiar micro e pequenas empresas (MPEs)" com faturamento de teto igual ao do SIMPLES federal, sendo que as micros estão isentas do ICMS, enquanto que as pequenas empresas podem recolher ICMS mediante uma alíquota que varia conforme o faturamento mensal. Mas somente "são beneficiadas as MPEs que vendem somente para o consumidor final e que realizam venda de mercadorias (indústria ou comércio) e que prestam serviços de transporte interestadual e intermunicipal e de comunicação, porque serão casos considerados contribuintes do ICMS”.
} 
atividade econômica possui um faturamento acima do permitido pela lei. Uma vez que certas atividades econômicas não são contempladas pela lei do SIMPLES, essas atividades vetadas permitem identificar o impacto de se introduzir a lei. Ou seja, a lei permite dividir as firmas em dois grupos, classificando um como grupo de tratamento (compreendidas pela lei) e um grupo de controle (não compreendidas pela lei), de acordo com a natureza de sua atividade econômica e receita.

Monteiro e Assunção (2004) foram os autores pioneiros em analisar o impacto do SIMPLES na formalização e investimento das micro e pequenas empresas brasileiras. A base de dados utilizada foi a ECINF, realizada pelo IBGE, com data de referência de outubro de 1997, ou seja, 10 meses após a lei ter sido sancionada. Os resultados obtidos revelam que a introdução do SIMPLES teve impacto positivo sobre a regularização das firmas, ou seja, a lei aumentou a probabilidade dessas firmas se regularizarem. 


\section{DADOS, MÉTODOS E PROCEDIMENTOS DE PESQUISA}

Esta seção apresenta os dados e a metodologia utilizada na pesquisa, definindo-se inclusive os cortes necessários para construção da base de dados.

\subsection{CONDUÇÃO DO ESTUDO}

Para tratarmos do nosso objeto de estudo (o empregado de firmas com até 5 empregados), utilizamos os microdados da pesquisa Economia Informal Urbana (ECINF) de outubro de 2003, disponibilizados pelo IBGE em parceria com o SEBRAE. Esta pesquisa foi aplicada para cerca de 55 mil entrevistados, focando apenas empreendimentos econômicos formados por trabalhadores por conta-própria e empregadores com até 5 empregados.

A ECINF 2003 detectou a existência de cerca de 10,3 milhões de empreendimentos informais, representando os empregadores $12,0 \%$ desse total, sendo os demais trabalhadores por conta própria. O número total de pessoas ocupadas em todos os empreendimentos atinge cerca de 13,9 milhões, o que representa, em 2003, cerca de $27 \%$ do total do emprego no Brasil (NERI, 2005).

Esses microdados constituem um corte no tempo (transversal) e não ao longo do tempo (longitudinal). É uma amostra probabilística de domicílios e compreende pouco mais de 70 mil firmas. A pesquisa da ECINF 2003 é representativa das regiões urbanas de todos os estados da federação brasileira e foi conduzida em duas etapas. Primeiro, domicílios foram 
selecionados com base na estrutura do censo de 2000, ou seja, com probabilidade proporcional à porcentagem de domicílios que se declararam ocupados em 2000. Posteriormente, domicílios com empregados próprios ou empregadores de até 5 empregados foram dispostos de acordo com a atividade econômica — seja ela a atividade principal ou secundária de seus proprietários — e selecionados com probabilidade uniforme em cada estrato.

A ECINF 2003 nada mais é do que uma edição mais atual da pesquisa que constituiu a ECINF 1997 e com questionários mais abrangentes, sendo baseada sobre os mesmos procedimentos e desenho amostral da edição de 1997. Os dados disponíveis incluem informações sobre a unidade econômica, o proprietário e o pessoal ocupado.

Como o interesse da pesquisa é no empregado de microempreendimentos econômicos, só foram utilizados dados de empregadores, isto é, os trabalhadores por conta-própria foram excluídos da amostra. E, a partir da variável de condição de ocupação presente na ECINF, foi identificado se os empregados de tais empregadores tinham ou não carteira de trabalho assinada. É importante dizer que a ECINF só cobre empregadores com até cinco empregados. Nesse sentido, está-se analisando uma amostra selecionada de empregadores ${ }^{\square}$

\subsection{PROCEDIMENTOS E INSTRUMENTOS DE PESQUISA}

Qualquer investigação emerge de um problema, de modo que não é possível prosseguir, a menos que se faça uma seleção da matéria a ser tratada na pesquisa. (CERVO; 
BERVIAN, 2002). Quanto à escolha do método de pesquisa, depende de dois fatores principais: o estado do conhecimento do tema investigado na literatura e do enfoque que o investigador pretende dar ao seu estudo (SAMPIERI; COLLADO; LUCIO,1994).

O método de pesquisa utilizado, procedimentos e instrumentos de pesquisa utilizados tomam por base os trabalhos de Monteiro e Assunção (2004) e Monteiro (2004). Esses autores, como colocado anteriormente, estimam o efeito do SIMPLES na formalização das empresas. Sendo assim, sua unidade de observação é a firma.

Nesta dissertação, entretanto, a unidade de observação são os trabalhadores. Uma outra diferença com relação ao trabalho desses autores é que, enquanto eles trabalham apenas com firmas de trabalhadores por conta-própria, nessa dissertação trabalha-se, por motivos já apresentados, apenas com empregadores. Essa distinção entre trabalhadores por conta-própria e empregadores é relevante, uma vez que esses dois tipos de categorias podem ter estruturas produtivas diferentes, por exemplo.

Como colocado inicialmente, o objetivo desse estudo é investigar o impacto da formalidade da empresa sobre a formalidade de seus empregados. Entretanto, muito provavelmente, existe alguma característica não observável que está associada com a probabilidade da firma ter licença, que é correlacionada com a probabilidade do empregado ter carteira de trabalho. Como essas relações não são observáveis, tudo o que não é explicado vai para o resíduo, criando-se uma situação de endogeneidade ${ }^{[}$. Por exemplo, firmas com mais tecnologia devem ter mais incentivo em ser formal e manter seu empregado formal, visando adquirirem maior estabilidade, em função dos gastos com treinamento. Esse empregado, por sua vez, quer mais estabilidade e também deve procurar se empregar em

\footnotetext{
${ }^{4}$ De acordo com Néri (2005), que faz um zoom com a base de dados da PNAD no universo da ECINF, esta última, por se restringir aos empregadores com até 5 empregados em sua pesquisa, propicia um recorte que exclui cerca de $26 \%$ dos empregadores (com mais de 6 empregados), segundo dados da PNAD.

${ }^{5}$ Está-se considerando endogeneidade como algo causado por variáveis omitidas, que impedem uma estimação consistente de uma relação causal, fazendo os coeficientes estimados não convergirem para os parâmetros populacionais.
} 
empresas formais. A tecnologia afeta a probabilidade da firma ser formal e de seu trabalhador ser formal. Isso vai para o resíduo e há endogeneidade.

Parte do procedimento do presente trabalho refere-se a classificar as firmas em dois grupos (tratamento e controle), algo possível com a Lei do SIMPLES, conforme mencionado na seção 2.4, porque o grupo de tratamento funcionará como a variável instrumental do modelo econométrico que é usado neste trabalho. Entretanto, a lista disponível de atividades vetadas, que pode ser usada para montar o grupo de comparação, é exemplificativa e não exaustiva. Na prática, de acordo com a Secretaria da Receita Federal, "só é possível saber, dependendo da atividade, se será permitido aderir ao SIMPLES após enviar o processo à Receita Federal e receber aprovação”. Como conseqüência de não se saber, previamente, qual atividade é vetada e qual é atingida pela lei, a solução encontrada foi semelhante à realizada por Monteiro e Assunção (2004) de manter o grupo de tratamento composto com firmas com probabilidade positiva de poder aderir à legislação e o grupo de comparação por firmas com probabilidade nula de ser atingidas pela Lei.

Pertencer ao grupo de tratamento, definida no presente trabalho como uma variável binária (1 caso a firma seja abrangida pelo SIMPLES federal de dezembro de 1996) que funciona como variável instrumental, é, antes de tudo, uma variável exógena, por se tratar de uma política econômica, que é exógena por natureza. A formalização do trabalhador será definida pela posse de carteira de trabalho assinada (será portanto a variável dependente).

As Tabelas A1 e A2, no apêndice, remetem as atividades econômicas do grupo de tratamento e controle, respectivamente. Além disso, a Tabela A3 lista as atividades que foram excluídas da análise, por não estar claro se pertencem ao grupo de tratamento ou comparação. A construção dos grupos de tratamento e comparação só foi possível de ser realizada porque a ECINF de 2003 possibilita, através de um código de atividade ${ }^{\text {耳 }}$, a identificação da atividade

\footnotetext{
${ }^{6}$ Há aproximadamente 140 códigos de atividades, entre atividades vedadas e sujeitas a Lei.
} 
desenvolvida por cada unidade econômica. Esse código de atividade permite comparar se a atividade está sujeita ou vedada pela Lei.

Com relação à variável que indica formalidade da firma, optou-se por utilizar o mesmo procedimento de Monteiro (2004), que utiliza a posse de licença municipal ou estadual como proxy de situação de regularidade da firma. A explicação do uso de licença como proxy de firmas formais, ao invés de $\mathrm{CGC/CNPJ}$, deve-se à forma como o questionário da ECINF foi realizado. A justificativa deve-se ao fato de que a pergunta sobre a posse de licença é feita para todos, independente das respostas anteriores. Já em relação ao CGC/CNPJ, nem todas firmas respondem: primeiro, questiona-se se a empresa possui constituição jurídica. Apenas em caso afirmativo, as perguntas seguintes - que incluem o CNPJ da firma, se possuem registro de microempresa e a forma de pagamento do imposto de renda - são respondidas (MONTEIRO; ASSUNÇÃO, 2004).

No que tange à metodologia, uma outra parte importante refere-se ao espaço temporal utilizado. Utiliza-se neste estudo apenas firmas criadas a partir de novembro de 1994 em diante, porque se usássemos todas as firmas da base de dados, as firmas criadas há vários anos anteriores poderiam contaminar os resultados posteriores, uma vez que as condições econômicas e institucionais antes do Plano Real seriam bem distintas.

No exercício empírico trabalha-se com duas amostras diferentes. Na primeira estimação, utiliza-se todas as firmas criadas entre novembro de 1994 e outubro de 2003 (mês em que foi realizada a pesquisa da ECINF 2003), ou seja, toda a amostra. E na segunda estimação usa-se um filtro, considerando-se apenas firmas criadas antes do SIMPLES e após o Plano Real.

Essa estimação com uso de filtro é considerada nesse trabalho a mais correta, pois no questionário da pesquisa da ECINF 2003 encontram-se informações referentes a possuir ou não licença municipal e / ou estadual, porém, não é questionado em que momento no tempo a 
licença foi obtida. Caso fossem consideradas firmas criadas antes e também após à lei, estariase considerando que firmas criadas antes e depois da lei teriam o mesmo estímulo para obterem licença, o que não parece correto.

O que se propõe neste trabalho é fazer uso de um filtro que utiliza apenas firmas criadas antes da lei existir e depois do Plano Real. O motivo de adotar o filtro considerando apenas firmas criadas antes da lei deve-se ao fato de que uma lei só é um evento exógeno para firmas criadas antes dela existir. As firmas criadas depois da lei acontecer não tem o SIMPLES como exógeno, por isso usa-se filtro mesmo controlando para ano de criação da empresa.

\subsubsection{O MODELO COM VARIÁVEIS INSTRUMENTAIS (VI)}

Outra distinção usada nesta dissertação é utilizar firmas que exerçam atividades com probabilidade diferente de zero de aderir à lei do SIMPLES. Essas firmas tratadas como candidatas à lei fazem o papel de variável instrumental ${ }^{7}$, como será detalhado. $\mathrm{O}$ método adotado é o de Mínimos Quadrados Ordinários em dois Estágios (MQ2E) e a técnica são os procedimentos descritos a seguir.

No primeiro estágio, para associar o impacto estimado ao SIMPLES, assume-se que a probabilidade das firmas, do grupo de tratamento e do grupo de controle, terem licença antes

\footnotetext{
${ }^{7} \mathrm{O}$ estimador de variável instrumental de $\beta$ possui uma variedade de nomes: estimador de variável instrumental (IV), estimador de variável instrumental generalizado (GIVE), ou estimador de mínimos quadrados em dois estágios (2SLS). Uma boa opção é referir-se a ele como estimador de IV em vez de 2 SLS porque a idéia de usar instrumento é central, e porque ele pode ser calculado em um passo assim como em dois (BAUM; SCHAFFER; STILLMAN, 2001, p.4. Tradução própria). Além disso, quando há apenas um instrumento para a variável potencialmente endógena, dizer estimador de MQ2E e estimador de VI é a mesma coisa (WOOLDRIDGE, 2002, p.92. Tradução própria).
} 
da lei do SIMPLES era a mesma. Isto quer dizer que, por hipótese, a probabilidade das firmas dos dois grupos, condicional em w (variáveis explicativas), de possuírem licença antes da lei era a mesma. Mais especificamente:

$$
\operatorname{Prob}\left(\mathrm{L}_{\mathrm{t}-1}{ }^{\mathrm{T}} \mid \mathrm{w}\right)=\operatorname{Prob}\left(\mathrm{L}_{\mathrm{t}-1}{ }^{\mathrm{C}} \mid \mathrm{w}\right)
$$

onde Prob $\left(\mathrm{L}_{\mathrm{t}-1}{ }^{\mathrm{T}} \mid \mathrm{w}\right)$ é a probabilidade da firma do grupo de tratamento possuir licença no instante anterior ao SIMPLES, condicional em w, que é o vetor de características exógenas às firmas; e (Prob $\left.\mathrm{L}_{\mathrm{t}-1}{ }^{\mathrm{T}} \mid \mathrm{w}\right)$ é a probabilidade de firma do grupo de controle possuir licença no instante anterior ao SIMPLES, condicional em w.

Dessa forma, o coeficiente associado a dummy tratamento na equação onde a probabilidade da firma ter licença é a variável dependente, se positivo, indica que a probabilidade das firmas do grupo de tratamento possuírem licença depois de introduzido o SIMPLES é superior ao das firmas do grupo controle, olhando para 2003, ano em que a pesquisa da ECINF foi realizada. Mais especificamente:

$$
\operatorname{Prob}\left(\mathrm{L}_{\mathrm{t}}{ }^{\mathrm{T}} \mid \mathrm{w}\right)>\operatorname{Prob}\left(\mathrm{L}_{\mathrm{t}}{ }^{\mathrm{C}} \mid \mathrm{w}\right)
$$

onde Prob $\left(\mathrm{L}_{\mathrm{t}}{ }^{\mathrm{T}} \mid \mathrm{w}\right)$ é a probabilidade da firma do grupo de tratamento possuir licença no instante posterior ao SIMPLES, condicional em w; e Prob $\left(\mathrm{L}_{\mathrm{t}}{ }^{\mathrm{C}} \mid \mathrm{w}\right)$ é a probabilidade da firma do grupo de controle possuir licença no instante posterior ao SIMPLES, condicional em w.

\footnotetext{
${ }^{8}$ Por método entende-se o procedimento sistemático, em plano geral. A técnica é a aplicação do plano metodológico e o modo de o executar, ou seja, é o conjunto dos passos ou procedimentos que devem ser dados para realização da pesquisa, de modo que a técnica está subordinada ao método (CERVO, BERVIAN, 2002).
} 
Esse procedimento adotado é diferente do apresentado por Monteiro (2004). Exemplificando, Monteiro (2004) adota, em linhas gerais, a seguinte regressão:

$\mathrm{Y}_{\mathrm{jt}=} \delta_{1} \mathrm{I}_{\mathrm{g}}+\delta_{2} \mathrm{I}_{\mathrm{t}}+\delta_{3} \mathrm{I}_{\mathrm{gt}}+\beta \mathrm{X}_{\mathrm{it}}+\mathrm{U}_{\mathrm{it}}$

onde $\mathrm{Y}_{\mathrm{jt}} \mathrm{e}$ uma dummy igual a 1 se a firma tem licença; $\mathrm{I}_{\mathrm{g}}$ é uma dummy igual a 1 se a firma pertence ao grupo de tratamento; $I_{t}$ é indica se a firma foi criada depois da lei do SIMPLES; $I_{g t}$ é uma interação entre $I_{g}$ e $I_{t}$, tendo valor 1 se a firma foi criada após a lei e integra o grupo tratamento e $\mathrm{X}_{\mathrm{it}}$ é um vetor de variáveis de controle.

Com o resultado (esperado) da regressão que assume a variável licença como dependente, tem-se a variável licença estimada, denominada nesse trabalho por "licença". Na segunda etapa faz-se outra regressão, mas agora com a variável binária “carteira” em função da "licença" e das demais variáveis da etapa imediatamente anterior, com exceção da variável "treat", que agora encontra-se implícita em "licença" estimada.

Formalmente, a equação a estimar é, baseado principalmente em Wooldridge (2002, p. 83):

$\mathrm{Y}=\beta_{0}+\beta_{\mathrm{j}} \mathrm{x}_{\mathrm{j}}+\beta_{\mathrm{k}} \mathrm{x}_{\mathrm{k}}+\mathrm{u}$

De modo que

$E(u)=0, \quad \operatorname{Cov}\left(x_{j}, u\right)=0 \quad j=1,2, \ldots K-1$

onde Y é a variável binária de interesse que indica posse de carteira de trabalho, $\mathrm{x}_{\mathrm{j}}$ é o vetor de variáveis explicativas exógenas descritas no quadro abaixo, e $\mathrm{x}_{\mathrm{k}}$ é a variável potencialmente endógena (porcentagem de firmas que possuem licença): 


\begin{tabular}{|c|c|}
\hline Variáveis & Descrição \\
\hline \multicolumn{2}{|l|}{ Variáveis relacionadas ao empregado } \\
\hline Parentes & $1=$ empregado possui parentesco com empregador \\
\hline Sexo & $1=$ homem \\
\hline Idade; idade2 & $\begin{array}{l}\text { Variáveis que captam idade e idade ao quadrado do } \\
\text { empregado }\end{array}$ \\
\hline Educ1...educ6 & $\begin{array}{l}\text { conjunto de dummies que captam educação do } \\
\text { trabalhador }\end{array}$ \\
\hline \multicolumn{2}{|l|}{ Variáveis relacionadas ao proprietário } \\
\hline Educ1p...educ6p & $\begin{array}{l}\text { conjunto de dummies que captam a educação do } \\
\text { empregador (proprietário da firma) }\end{array}$ \\
\hline \multicolumn{2}{|l|}{ Variáveis relacionadas à firma } \\
\hline K_prop & $\begin{array}{l}1 \text { = utiliza algum tipo de recurso próprio apenas como } \\
\text { principal origem do capital necessário para abrir o } \\
\text { negócio. }\end{array}$ \\
\hline Outr_job & 1 = firmas cujo proprietário tem outro trabalho \\
\hline Fora_Dom & $\begin{array}{l}1=\text { unidade econômica fora do domicílio em que } \\
\text { reside o proprietário }\end{array}$ \\
\hline Vend_gov & $\begin{array}{l}\text { 1= venda de produtos para grandes firmas ou ao } \\
\text { governo }\end{array}$ \\
\hline Subcontr_princ & $\begin{array}{l}\text { 1= unidade econômica que trabalhava exclusiva ou } \\
\text { principalmente por encomenda ou subcontratação. }\end{array}$ \\
\hline Registro1 & $\begin{array}{l}1=\text { unidade econômica que registra as contas do } \\
\text { negócio }\end{array}$ \\
\hline Patr_peq; patr_med; patr_gde & $\begin{array}{l}\text { Conjunto de dummies que medem o patrimônio da } \\
\text { empresa. }\end{array}$ \\
\hline $\mathrm{SE} ; \mathrm{S}, \mathrm{CO} ; \mathrm{N} ; \mathrm{NE}$ & $\begin{array}{l}\text { Conjunto de dummies de cada região brasileira em que } \\
\text { se localiza o negócio }\end{array}$ \\
\hline $\begin{array}{l}\text { Ind, Transfor e extrat; Construc civil; Comérc e } \\
\text { reparação; Transp, armaz e comunic; Ativis imobil, } \\
\text { alug e servs para firmas; Saúde, educ e servs sociais; } \\
\text { Outras }\end{array}$ & $\begin{array}{l}\text { Conjunto de variáveis dummies de grupos de } \\
\text { atividades econômicas das empresas. }\end{array}$ \\
\hline Ano & $\begin{array}{l}\text { Conjunto de variáveis dummies que indicam o ano de } \\
\text { criação da empresa. }\end{array}$ \\
\hline
\end{tabular}

Quadro 1 - Descrição das variáveis utilizadas na análise descritiva

Fonte: (IBGE; ECINF, 2003) - Elaboração própria 
A dummy parentesco com o empregador mede se o empregado tinha alguma relação de parentesco com o proprietário da firma (filho, cônjuge ou outro parente) dado que ser parente ou não pode ser relevante para aumentar a chance de ter carteira de trabalho assinada. A dummy sexo (homem) serviu para observarmos distinções entre homens e mulheres. Utilizaram-se variáveis contínuas apenas para idade e idade2 do empregado. O conjunto de dummies "educ1" à "educ6" captam a escolaridade do empregado, enquanto "educ1p" à “educ6p" estão captando a escolaridade do proprietário da firma. A dummy "k_prop”, diz se a principal origem do capital para abrir o empreendimento econômico foi recurso próprio do proprietário. "Outr_job" indica se o proprietário possui outro emprego além de ser empregador em seu negócio. "Fora_dom" indica se a unidade econômica é localizada fora do domicílio em que o empregador reside. "Vend_gov" diz se a unidade econômica vende seus produtos ao governo ou para grandes firmas. "Subcontr_princ" indica se a firma trabalha por meio de encomendas ou subcontratação como atividade principal ou exclusiva. "registro1" diz se a firma possui algum modo de registrar as contas do negócio. Com relação ao patrimônio, medido pelo valor total das instalações e equipamentos, está-se referindo ao valor, caso fosse vendido, da instalação e/ou equipamento mais utilizado na firma. Seus valores foram dispostos entre as dummies "firm_peq", representando firmas com patrimônio menor do que o valor de patrimônio que define o $33^{\circ}$ percentil dos valores do patrimônio (patrimônio de até 1600 reais), "firm_med", que define o $34^{\circ}$ ao $66^{\circ}$ percentil dos valores do patrimônio (patrimônio entre 1600 reais e 5000 reais) e "firm_gde", representando firmas com patrimônio maior que o $66^{\circ}$ percentil dos valores do patrimônio (patrimônio superior a 5000 reais). Em seguida, o quadro acima mostra o conjunto de dummies que controlam as regiões geográficas em que se encontram as unidades econômicas. Abaixo delas, encontram-se o conjunto de dummies que controlam para grupos de atividades econômicas das firmas, seguido pelo conjunto de dummies que controlam para ano de criação das firmas. 
Em função da endogeneidade de $x_{k}$ utilizou-se o método de variáveis instrumentais ${ }^{Q}$ (VI) ou de mínimos quadrados em dois estágios (MQ2E) . O instrumento é a variável "treat", dummy que indica as atividades econômicas que podem aderir à legislação do SIMPLES, conforme descrito anteriormente.

O método das variáveis instrumentais tem a propriedade de fornecer uma solução geral para o problema de uma variável explicativa endógena, ao dissipar a simultaneidade entre $\mathrm{Y}$ e $\mathrm{x}_{\mathrm{k}}$, possibilitando medir o impacto do fato da firma possuir licença e das diversas características da firma sobre as chances do empregado possuir carteira de trabalho assinada.: "One solution to the omitted variables problem is to assign the variable of interest randomly" (ANGRIST; KRUEGER, 2001).

Para isso, faz-se necessário que a variável instrumental preencha dois requisitos. Primeiro, ela não pode ser correlacionada com u, ou seja,

$\operatorname{Cov}(\mathrm{z}, \mathrm{u})=0$

Onde zé a dummy “treat".

A segunda condição é que "treat" seja correlacionada com $\mathrm{x}_{\mathrm{k}}$, ou seja, Cov $\left(\mathrm{z}, \mathrm{x}_{\mathrm{k}}\right) \neq 0$ e $\theta_{1} \neq 0 \mathrm{em}:$

$\mathrm{x}_{\mathrm{k}}=\delta_{0}+\delta_{\mathrm{j}} \mathrm{x}_{\mathrm{j}}+\theta_{1} \mathrm{z}+\mathrm{r}_{\mathrm{k}}$

que é conhecida como equação na forma reduzida para $\mathrm{x}_{\mathrm{k}}$, onde

\footnotetext{
${ }^{9}$ Para tornar a explicação mais clara, é bom saber que a estimação por Mínimos Quadrados Ordinários é consistente sob a hipótese $\operatorname{cov}\left(\mathrm{u}_{\mathrm{i}}, \mathrm{x}_{\mathrm{i}}\right)=0$ e não viesado sob a hipótese $\mathrm{E}\left(\mathrm{u}_{\mathrm{i}} \mid \mathrm{x}_{\mathrm{i}}\right)=0$. Quando essas condições são violadas, é necessário obter um novo método de estimação. O método de variáveis instrumentais (VI) é uma solução possível que fornece estimadores consistentes dos parâmetros de interesse.
} 
$E\left(r_{k}\right)=0$ e $\operatorname{Cov}\left(r_{k}, x_{j}\right.$ e $\left.z\right)=0 \quad j=1,2, \ldots K-1$

Satisfazendo essas duas condições mencionadas, z passa a ser um candidato à VI ( ou simplesmente instrumento) para $\mathrm{x}_{\mathrm{k}}$. Em outras palavras, o método de variáveis instrumentais permite estimar o coeficiente de interesse consistentemente e livre de viés assintótico da variável omitida, sem precisar ter dados sobre a variável omitida e nem mesmo conhecer o que ela é. A intuição por trás do método é que, como variáveis instrumentais resolvem o problema da variável omitida por usar apenas parte da variabilidade da variável potencialmente endógena (licença no caso) que é não correlacionada com a variável omitida, torna-se possível estimar a relação entre licença e carteira (ANGRIST; KRUEGUER, 2001).

O método dos MQ2E, que é adotado, possui forma linear. Os possíveis problemas mais comuns, decorrentes de utilizar um modelo de probabilidade linear, é que este modelo pode apresentar alguns problemas, como valores fora do intervalo $(0,1)$ para probabilidade e a presença de heteroscedasticidade. Para lidar com esses possíveis problemas, utiliza-se desvio-padrão robusto ${ }^{10}$ para corrigir heteroscedasticidade por meio do comando robust no software adotado, que foi o Stata 9.2. Quanto aos valores que ultrapassam o intervalo entre (0, 1), adota-se o procedimento de ajustar os valores previstos das regressões no primeiro estágio para dentro do intervalo ${ }^{1}$, para, assim, usar esse valor previsto como variável explicativa para a variável dependente no segundo estágio. Esse procedimento não altera o resultado final e, além disso, a consistência dos MQ2E não depende da exatidão da forma linear do primeiro estágio (KELEJIAN, 1971).

\footnotetext{
${ }^{10}$ É utilizado desvio padrão robusto para estimar modelo adotado, obtendo-se variância robusta na matriz de variância-covariância, ou seja, ainda que possa mudar o desvio padrão, o coeficiente permanece o mesmo. De acordo com Baum, Schaffer e Stillman (2002), na presença de heteroscedasticidade, o estimador de VI é ineficiente mas consistente, ao passo que o desvio-padrão estimado da matriz de covariância de VI é inconsistente.

${ }^{11}$ Os valores que ultrapassam o intervalo desejado $(0,1)$ não afetam o resultado final, uma vez que, sem ajustar o valor previsto, encontrou-se resultado bem próximo do apresentado neste trabalho. Os percentis indicando os valores que extrapolam o intervalo encontram-se no APÊNDICE B.
} 
Utilizando-se esse método de estimação, faz-se uma regressão no primeiro estágio no banco de firmas, relacionando a licença à variável instrumental (atividades abrangidas pelo SIMPLES) e outras variáveis exógenas. Calcula-se o valor previsto por essa regressão para utilizá-los como regressor na equação principal. Com esse procedimento, espera-se identificar o efeito do fato das firmas terem licença sobre o fato de seus trabalhadores terem carteira de trabalho.

Aqui é importante uma observação. Temos dois bancos de dados: um de firmas e um de empregados. Logicamente, os empregados de uma determinada firma têm a mesma identificação de sua empregadora. Como a variável de interesse é carteira do empregado (que identifica o empregado), trabalhamos com o banco de empregados. Mas isso traz o inconveniente de distorcer qualquer estatística descritiva que tivesse interesse nas firmas, porque uma única firma que empregasse " $n$ " empregados, seria representada por " $n$ " vezes. Por essa razão, realiza-se o primeiro estágio em um banco de firmas, em que a unidade de observação é a firma. Quanto ao segundo estágio, é realizada no banco de empregados. 


\section{ANÁLISE DESCRITIVA E RESULTADOS}

Nesta seção apresenta-se a relação das estatísticas descritivas utilizadas na estimação econométrica do modelo sugerido, bem como os principais resultados referentes à significância estatística do impacto das variáveis explicativas sobre a probabilidade de ter posse de carteira de trabalho.

\subsection{ANÁLISE DESCRITIVA}

Todas as tabelas a seguir, com exceção da Tabela 7, contém dados expandidos, ou seja, ponderados pelos respectivos pesos amostrais. Tomando-se o território brasileiro como um todo, temos a seguinte distribuição geográfica dos empregados que trabalham nos pequenos empreendimentos, que por sua natureza concentram uma grande parte de trabalhadores informais: 
Tabela 1 - Proporção de empregados em micro e pequenas empresas, segundo a posse de carteira de trabalho e as grandes regiões (2003)

\begin{tabular}{lccccccc}
\hline \% de empregados & \multicolumn{7}{c}{ Região } \\
\cline { 2 - 8 } & $\mathrm{SE}$ & $\mathrm{S}$ & $\mathrm{CO}$ & $\mathrm{NE}$ & $\mathrm{N}$ & $\begin{array}{c}\text { Brasil } \\
(\boldsymbol{\%})\end{array}$ & $\begin{array}{c}\text { Brasil } \\
\text { (absoluto) }\end{array}$ \\
\hline $\begin{array}{l}\text { \% de trabalhadores sem } \\
\text { carteira na região }\end{array}$ & 60,64 & 42,18 & 61,15 & 74,96 & 83,69 & $\mathbf{6 1 , 0 4}$ & $\mathbf{6 3 5 . 5 5 8}$ \\
$\begin{array}{l}\text { \% de trabalhadores com } \\
\text { carteira na região }\end{array}$ & 39,36 & 57,82 & 38,85 & 25,04 & 16,31 & $\mathbf{3 8 , 9 6}$ & $\mathbf{4 0 5 . 6 1 3}$ \\
\hline \% de trabalhadores (total) & $\mathbf{4 1 , 5 9}$ & $\mathbf{2 2 , 4 6}$ & $\mathbf{8 , 7 2}$ & $\mathbf{2 0 , 2 8}$ & $\mathbf{6 , 9 5}$ & $\mathbf{1 0 0 , 0 0}$ & $\mathbf{1 . 0 4 1 . 1 7 1}$ \\
\hline
\end{tabular}

\begin{tabular}{lccccccc}
\hline \% de licenças & \multicolumn{7}{c}{ Região } \\
\cline { 2 - 8 } & SE & S & CO & NE & N & $\begin{array}{c}\text { Brasil } \\
\text { (\%) }\end{array}$ & $\begin{array}{c}\text { Brasil } \\
\text { (absoluto) }\end{array}$ \\
\hline $\begin{array}{l}\text { \% de firmas sem licença na } \\
\text { região }\end{array}$ & 41,80 & 21,12 & 29,36 & 47,83 & 48,01 & $\mathbf{3 8 , 1 1}$ & $\mathbf{2 2 9 . 9 8 2}$ \\
$\begin{array}{l}\text { \% de firmas com licença na } \\
\text { região }\end{array}$ & 58,20 & 78,88 & 70,64 & 52,17 & 51,99 & $\mathbf{6 1 , 8 9}$ & $\mathbf{3 7 3 . 4 3 2}$ \\
\hline \% de firmas (total) & $\mathbf{4 2 , 9 7}$ & $\mathbf{2 0 , 9 1}$ & $\mathbf{8 , 4 1}$ & $\mathbf{2 0 , 2 9}$ & $\mathbf{7 , 4 2}$ & $\mathbf{1 0 0 , 0 0}$ & $\mathbf{6 0 3 . 4 1 4}$ \\
\hline
\end{tabular}

Fonte: (IBGE; ECINF, 2003) - Elaboração própria.

De acordo com a Tabela 1 acima, do total dos empregados do Brasil (com carteira e sem carteira) que trabalham em firmas de até 5 empregados, a maior parte concentra-se na região sudeste $(41,59 \%)$, seguida da região sul $(22,46 \%)$, nordeste $(20,28 \%)$, centro-oeste $(8,72 \%)$ e por último norte $(6,95 \%)$.

A Tabela 1 mostra ainda que a região brasileira que possui proporcionalmente a maior parte de trabalhadores com carteira de trabalho, nesses pequenos empreendimentos, é a região sul $(57,82 \%)$, que é a única região brasileira que possui percentualmente mais empregados formalizados. No outro extremo, a região com menos empregados formalizados, em relação ao número total de empregados na sua própria região, é a região norte $(16,31 \%)$. As explicações para essas diferenças observadas entre empregados sem carteiras de trabalho entre as regiões brasileiras podem ser as mais diversas. 
Em relação ao total de firmas, sua distribuição geográfica é semelhante ao de empregados, pois as firmas concentram-se mais na região sudeste e menos na região norte. Porém, uma diferença que se observa entre firmas e seus empregados é que a maior parte das firmas analisadas possuem licença $(61,89 \%)$, ao passo que apenas $38,96 \%$ dos empregados dessas firmas possuem carteira de trabalho.

Do ponto de vista do desenvolvimento regional e estadual, o processo de industrialização acelerada da década de 1960 já explicitava desigualdades espaciais no Brasil. Mais atualmente, Oliveira e Guimarães Neto (1997), chama atenção para três aspectos (discutidos neste artigo muito sinteticamente) referentes às economias regionais brasileiras no período recente. O primeiro aspecto reconhece que há diferenças entre as taxas de crescimento médias das economias regionais, mas, em geral, a configuração da evolução das regiões tem sido a mesma, em seu conjunto. $\mathrm{O}$ segundo aspecto aponta que, pelo fato de as taxas serem distintas, isto possibilita, no decorrer de várias fases do desenvolvimento brasileiro (que foge ao escopo desta dissertação discuti-las), a uma maior concentração ou desconcentração espacial da atividade produtiva no país. Por fim, um terceiro aspecto relaciona-se às mudanças observadas nos anos 90, como o plano de estabilização do Real, abertura da economia e aprofundamento das estratégias empresariais devido a maior concorrência no mercado doméstico e estrangeiro, que não permitem ainda que as conseqüências dessas mudanças sejam totalmente claras, para que se tenha um juízo definitivo a respeito das mudanças espaciais das atividades econômicas. Além disso, inovações organizacionais e nos processos produtivos na década de 1990 reduziram os níveis de emprego, atingindo várias partes do país (OLIVEIRA; GUIMARÃES NETO, 1997).

Interpretação semelhante a quem tem Kon (2004). Esta defende a idéia de que, na atualidade, a condição de informalidade das atividades brasileiras é determinada por um lado por políticas públicas que priorizam a continuidade da estabilização 
econômica e, por outro, pelas transformações estruturais intensificadas e mais velozes manifestadas de forma diferenciada tanto em âmbito global, internacional quanto regional, e que resultam em formas também diversas de inserção do trabalho (KON, 2004, p. 4).

Numa visão não dissidente da anterior, pode-se dizer também que regiões que possuem economias mais desenvolvidas (tais como sul e sudeste), são onde se observam maior fiscalização e cumprimento das leis do trabalho, logo, maior é a parcela de empregos formais (DEDECCA, BALTAR, 1997, p.80).

A seguir, a Tabela 2 apresenta os dados com a distribuição dos trabalhadores através dos setores de atividade.

Tabela 2 - Proporção de empregados em micro e pequenas empresas, segundo a posse de carteira de trabalho e os grupos de atividade (2003)

\begin{tabular}{lccc}
\hline \multirow{2}{*}{ Grupo de atividade } & \multicolumn{3}{c}{ Proporção de empregados } \\
\cline { 2 - 4 } & $\begin{array}{c}\text { \% de trabalhadores } \\
\text { sem carteira }\end{array}$ & $\begin{array}{c}\text { \% de trabalhadores } \\
\text { com carteira }\end{array}$ & $\begin{array}{c}\text { \% de trabalhadores } \\
\text { (total) }\end{array}$ \\
\hline Comérc e reparação & 53,05 & 46,95 & $\mathbf{4 4 , 6 6}$ \\
Construc civil & 83,76 & 16,24 & $\mathbf{7 , 8 8}$ \\
Ind. Transfor e extrat & 68,31 & 31,69 & $\mathbf{1 3 , 0 9}$ \\
Transp, armaz e comunic & 74,15 & 25,85 & $\mathbf{5 , 4 4}$ \\
Alim e serv, alojam, & 70,20 & 29,80 & $\mathbf{6 , 4 1}$ \\
Ativs imobil, alug, e servs para firmas & 42,93 & 57,07 & $\mathbf{7 , 0 6}$ \\
Saúde, educ, e servs sociais & 49,88 & 50,12 & $\mathbf{6 , 5 3}$ \\
Outras & 78,19 & 21,81 & $\mathbf{8 , 9 3}$ \\
\hline
\end{tabular}

Fonte: (IBGE; ECINF, 2003) - Elaboração própria.

De acordo com a tabela 2, o grupo de atividade que possui proporcionalmente a maior parte de trabalhadores com carteira de trabalho em relação ao total de empregados é o que engloba atividades "imobiliárias, aluguéis e serviços prestados às empresas", representando 57,07\%, seguido de "educação, saúde e serviços sociais", com 50,12\%. Em seguida temos, “comércio e reparação" (46,95\%), “indústria de transformação e extrativa" (31,69\%), “serviços de alojamento e alimentação" (29,8\%), "transporte, armazenagem e comunicações" $(25,85 \%)$ e por fim “construção civil” (16,24\%). "Outras atividades” (que englobam outros 
serviços coletivos, sociais e pessoais e outras atividades) representam $21,81 \%$ de trabalhadores detentores de carteira de trabalho em relação ao total de trabalhadores.

Esse resultado, ao menos em seus extremos - "construção civil" de um lado e "atividades imobiliárias, aluguéis e serviços para firmas" mais "saúde, educação e serviços sociais de outro" - era esperado. Uma explicação provável é que "atividades imobiliárias, aluguéis e serviços para firmas", por serem provavelmente atividades contratadas por compradores muitas vezes formais, sentem-se impelidos a serem formais também. De acordo com De Paula e Scheinkman (2006), várias medidas de formalidade de ofertantes e compradores são correlacionadas com a formalidade da firma.

Com relação à "saúde, educação e serviços sociais", supõe-se que sejam atividades mais formalizadas (como cursos em geral e laboratórios). Já na "construção civil”, geralmente empreiteiras especializadas são contratadas por grandes empresas e entidades governamentais por exemplo, mas construções de famílias mais pobres ocorrem mais freqüentemente por pedreiros e seus auxiliares. Deve-se destacar também que microempresas do setor de construção civil possuem maior rotatividade da mão-de-obra que outros setores (CACCIAMALI; PIRES, 1997), o que poderia diminuir contratações com carteira de trabalho. Além disso, a informalidade é bem espalhada em decorrência da diferença de adaptabilidade das diferentes realidades regulatórias, tecnológicas e competitivas de cada grupo de atividade da economia.

A Tabela 2 indica também que a grande maioria do total de trabalhadores encontramse no setor de "comércio e reparação" $(44,66 \%)$, o que torna "Comércio e reparação" a atividade que compreende, em números absolutos, a maior parte dos trabalhadores sem carteira $(38,82 \%)$ e dos trabalhadores com carteira $(53,82 \%)$.

Empreendimentos com alto índice de empregados informais, como comércio (em termos absolutos) e construção (em termos absolutos e relativos), geralmente são pequenos 
em escala e geograficamente dispersos, dificultando a fiscalização. Como custos do trabalho são parte representativa dos gastos totais, as distorções competitivas geradas pela informalidade permeiam mais intensamente setores de atividade intensivos em trabalho do que intensivos em capital. Esse é, por exemplo, o caso da indústria de alimentos processados, onde o ganho de evadir tributos relacionados à folha de pagamentos podem ser grandes (FARREL, 2004, p.29).

Nesses setores intensivos em trabalho, não apenas firmas muito pequenas operam na informalidade, mas também firmas modernas. (CAPP; ELSTRODT; JONES JR, 2005). Uma possível explicação para isso é que o corte setor informal não tem necessariamente associação com baixo nível de renda ou pobreza de modo homogêneo, porque não é característica intrínseca ao setor informal suprir a demanda por bens serviços das camadas mais pobres no meio urbano embora a oferta deste setor se dirija também para esses grupos (CACCIAMALI, 1983).

Já a tabela 3 abaixo constata que do total de firmas informais (sem licença) a maior parcela dos empregados não possuem carteira, ou seja, são informais também (cerca de 92\%). Já entre firmas com licença, a proporção dos trabalhadores com carteira é relativamente maior, em cerca de 10 pontos percentuais, como segue abaixo:

Tabela 3 - Proporção de empregados com carteira e sem carteira de trabalho, segundo firmas com licença e sem licença (2003)

\begin{tabular}{lccc}
\hline $\begin{array}{c}\text { Proporção de empregados com ou } \\
\text { sem carteira }\end{array}$ & Firmas sem licença & Firmas com licença & Total \\
\hline Média de não possuir carteira & & & $\mathbf{6 1 , 0 4}$ \\
Média de possuir carteira & 91,99 & 44,97 & $\mathbf{3 8 , 9 6}$ \\
\hline Total (empregados) & 8,01 & 55,03 & $\mathbf{1 0 0 , 0 0}$ \\
\hline Média (empregados) & $\mathbf{1 0 0 , 0 0}$ & $\mathbf{1 0 0 , 0 0}$ & $\mathbf{- - - - -}$ \\
\hline
\end{tabular}

Fonte: (IBGE; ECINF, 2003) - Elaboração própria. 
Outro ponto possível de ser explorado é constatar se um empregador formal possui maior número de empregados que um informal, em termos relativos. Adotando a firma como unidade observacional, pode-se notar que firmas sem licença possuem, em média, 1,55 empregados, ao passo que firmas com licença, 1,84 empregados, corroborando as observações de De Paula e Scheinkman (2006), de que uma firma formal possui maior número de empregados que uma informal.

A partir de 1990, no Brasil, há início de um processo de crescimento até então não registrado no grau de informalidade no mercado de trabalho brasileiro, reafirmando o crescimento da pequena escala produtiva e do emprego à margem da regulamentação institucional. Ainda assim, de modo geral, há apenas dois consensos observados na literatura nacional em relação à informalidade no mercado de trabalho brasileiro: Um diz respeito à escolaridade dos trabalhadores sem carteira de trabalho assinada. Estes apresentam, em média, menos anos de estudo que os assalariados formais (NERI (2002). Um outro consenso diz respeito ao formato de $U$ da relação existente entre ser um trabalhador sem carteira de trabalho assinada e a idade. Isto significa que, até uma certa idade, a probabilidade de pertencer ao setor informal decresce, e após essa certa idade, cresce, conforme indicam Tannuri-Pianto e Pianto (2002 apud ULYSSEA, 2005a, p.4).

A Tabela 4 indica que, na média, a maior parte dos empregados (totais) do nosso universo amostral possuem nível de instrução referente ao $2^{\circ}$ grau completo $(32,43 \%)$, em relação ao total de empregados da amostra. Em seguida vêm os empregados com $1^{\circ}$ grau incompleto $(30,83 \%), 1^{\circ}$ grau $(16,64 \%), 2^{\circ}$ grau incompleto $(13,91 \%)$, superior incompleto $(3,99 \%)$ e, por fim, grau superior completo $(2,19 \%)$, como sendo menos representativo da população de empregados. Todas essas porcentagens educacionais referem-se ao total de empregados com o referente nível de instrução (por estrato), como é detalhado abaixo: 
Tabela 4 - Proporção de empregados, segundo o nível educacional e a posse ou não de carteira de trabalho (2003)

\begin{tabular}{|c|c|c|c|}
\hline \multirow{2}{*}{$\begin{array}{c}\text { Nível educacional do } \\
\text { empregado }\end{array}$} & \multicolumn{3}{|c|}{ Proporção de empregados } \\
\hline & \%de empregados informais & \% de empregados formais & $\begin{array}{c}\% \text { de empregados } \\
\text { (total) }\end{array}$ \\
\hline Até $1^{\circ}$ grau incompleto & 75,72 & 24,28 & 30,83 \\
\hline $1^{\circ}$ grau (completo) & 60,35 & 39,65 & 16,64 \\
\hline $2^{\circ}$ grau incompleto & 65,29 & 34,71 & 13,91 \\
\hline $2^{\circ}$ grau (completo) & 47,37 & 52,63 & 32,43 \\
\hline Superior incompleto & 54,03 & 45,97 & 3,99 \\
\hline Superior completo & 47,95 & 52,05 & 2,19 \\
\hline \multirow{2}{*}{$\begin{array}{c}\text { Nível educacional do } \\
\text { empregador }\end{array}$} & \multicolumn{3}{|c|}{ Proporção de empregados } \\
\hline & \% de empregados informais & $\%$ de empregados formais & $\begin{array}{c}\% \text { de empregados } \\
\text { (total) }\end{array}$ \\
\hline Até $1^{\circ}$ grau incompleto & 75,75 & 24,25 & 24,94 \\
\hline $1^{\circ}$ grau (completo) & 78,35 & 21,65 & 10,90 \\
\hline $2^{\circ}$ grau incompleto & 84,01 & 15,99 & 7,84 \\
\hline $2^{\circ}$ grau (completo) & 55,91 & 44,09 & 30,91 \\
\hline Superior incompleto & 49,13 & 50,87 & 8,63 \\
\hline Superior completo & 32,82 & 67,18 & 16,78 \\
\hline
\end{tabular}

Fonte: (IBGE; ECINF, 2003) - Elaboração própria.

$\mathrm{Na}$ amostra analisada neste trabalho, com relação à educação, observa-se que embora o percentual de empregados com carteira de trabalho assinada não cresça continuamente com os anos de estudo, há uma tendência de crescimento: a formalidade passa de $24,3 \%$ para os menos educados para 52,05\% para os mais educados.

Esta tabela mostra que é no grupo de trabalhadores com até o $1^{\circ}$ grau incompleto onde se encontra o menor percentual de detentores de carteira assinada, que é 24,28\%. Esse nível de escolaridade forma assim o ponto mais baixo de incidência de trabalhadores com carteira de trabalho. Já o grupo de empregados que possuem o $2^{\circ}$ grau e o superior completo apresentam um porcentual maior de detentores de carteira assinada, respectivamente $52,63 \% \mathrm{e}$ $52 \%$, constituindo os picos de incidência de empregados com carteira de trabalho. $\mathrm{Na}$ verdade, observa-se um 'efeito diploma' nessa distribuição, pois a taxa de formalidade 
diminui com o aumento dos anos de estudo quando os trabalhadores terminam ou completam um certo grau escolar.

Quando observa-se o nível de instrução do proprietário da firma que emprega esses trabalhadores, nota-se que proprietários com $2^{\circ}$ grau completo possuem mais empregados que proprietários com outros níveis de escolaridade. Já os proprietários com superior completo são os que possuem percentualmente mais empregados com carteira de trabalho $(67,18 \%)$.

A proporção da posse de carteira de trabalho, por estrato de escolaridade do empregado, e da posse de carteira de trabalho, por extrato de escolaridade do proprietário da firma, está apresentada no gráfico abaixo 2 .

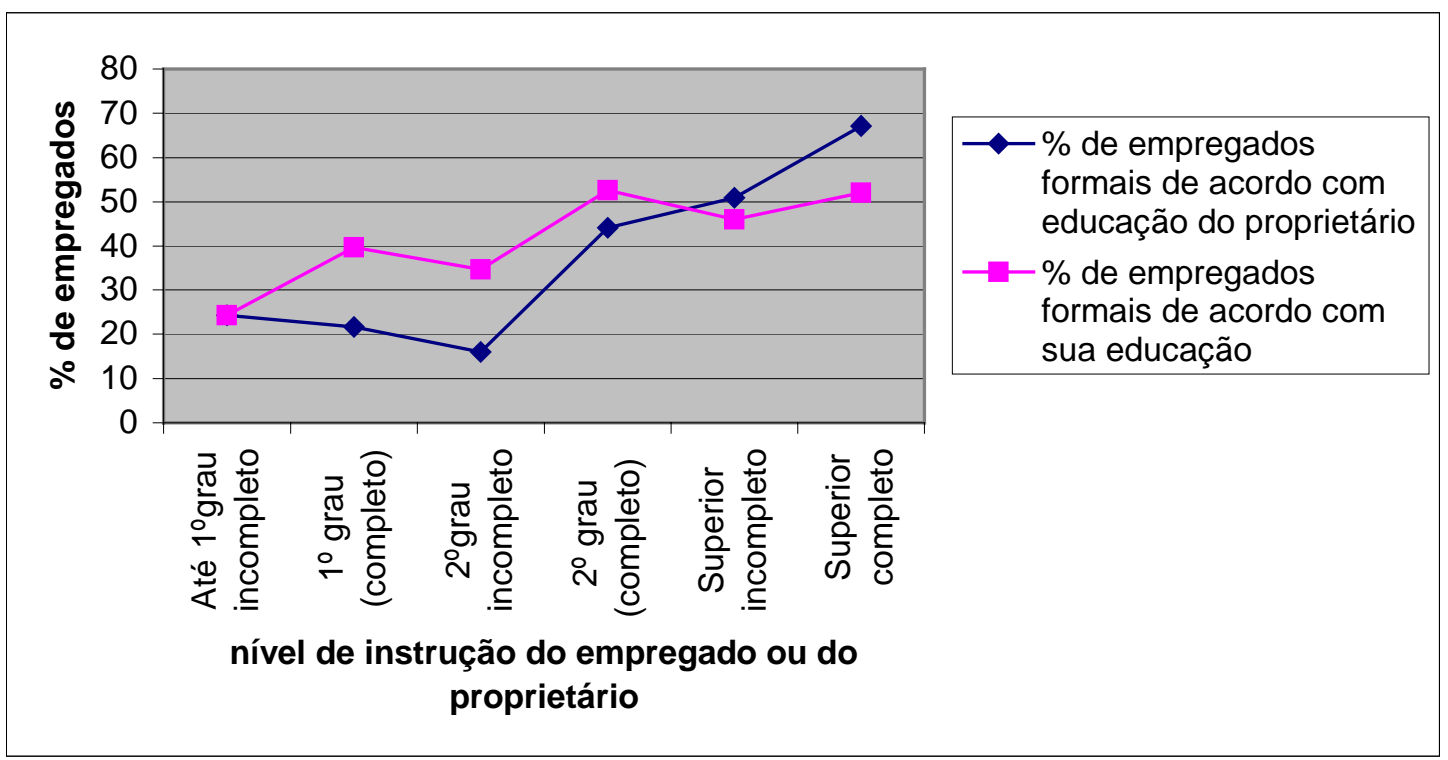

Gráfico 1 - Proporção de empregados com carteira de trabalho no nível de educação correspondente do proprietário ou do empregado.

Fonte: (IBGE; ECINF, 2003) - Elaboração própria.

Uma possível explicação para o fato da formalidade não crescer continuamente com a escolaridade pode ser porque a amostra que foi usada neste trabalho é específica para

\footnotetext{
${ }^{12}$ Nessa dissertação, o Gráfico 1, foi gerado no banco de trabalhadores
} 
unidades econômicas de até 5 empregados, como foi explicado na descrição dos dados. $\mathrm{Ou}$ seja, o universo de empregados que se analisa neste trabalho é portanto uma amostra selecionada. Outra possibilidade que poderia explicar essa descrição é que empregados com maior educação (superior incompleto e superior completo) que trabalham em estabelecimentos com até 5 empregados acabam tendo outra atividade remunerada.

Por outro lado, os resultados de Henley, Arabsheibani e Carneiro (2006) - que investigam o grau de congruência entre diferentes definições de informalidade usando a PNAD de 1992 a 2001 - estão em consonância com os encontrados aqui. Eles encontram que taxas de informalidade estão crescendo entre os mais habilidosos, enquanto taxas de formalidade estão crescendo entre os menos habilidosos. Além disso, o estudo mostra que, nesse período, dentre as três definições utilizadas para definir informalidade - carteira de trabalho, proteção da seguridade social, natureza do emprego e características do empregador - a informalidade definida de acordo com carteira de trabalho (ter ou não ter) é bem menos fortemente atrelado com o menor nível educacional do que em outras definições. Assim, esses resultados estão em consonância com os observados na Tabela 4.

A Tabela 5 analisa conjuntamente as variáveis grupo de atividade e instrução. 
Tabela 5 - Tabulação dos níveis de instrução como porcentagem do grupos de atividades

\begin{tabular}{|c|c|c|c|c|c|c|c|}
\hline \multirow{2}{*}{$\begin{array}{l}\text { Grupo de } \\
\text { atividade }\end{array}$} & \multicolumn{7}{|c|}{ Nível educacional } \\
\hline & $\begin{array}{l}\text { 10grau } \\
\text { incompl }\end{array}$ & $1^{\circ} \mathrm{grau}$ & $\begin{array}{l}\stackrel{2}{\circ} \text { grau } \\
\text { incompl }\end{array}$ & 2o grau & $\begin{array}{l}\text { Superior } \\
\text { incompl }\end{array}$ & $\begin{array}{l}\text { Superior } \\
\text { compl }\end{array}$ & $\begin{array}{c}\text { Total de } \\
\text { empregados } \\
\text { na atividade }\end{array}$ \\
\hline $\begin{array}{l}\text { Comérc e } \\
\text { reparação }\end{array}$ & $30,90 \%$ & $14,64 \%$ & $15,60 \%$ & $34,47 \%$ & $2,62 \%$ & $1,77 \%$ & $44,66 \%$ \\
\hline Construc civil & $59,20 \%$ & $18,80 \%$ & $7,14 \%$ & $13,31 \%$ & $0,99 \%$ & $0,56 \%$ & $7,88 \%$ \\
\hline $\begin{array}{l}\text { Ind. Transfor } \\
\text { e extrat. }\end{array}$ & $36,41 \%$ & $21,55 \%$ & $14,45 \%$ & $25,86 \%$ & $1,16 \%$ & $0,57 \%$ & $13,09 \%$ \\
\hline $\begin{array}{l}\text { Transp, } \\
\text { armaz e } \\
\text { comunic. } \\
\text { Alimen e serv, } \\
\text { alojam. }\end{array}$ & $43,57 \%$ & $20,51 \%$ & $15,15 \%$ & $30,10 \%$ & $2,12 \%$ & $0,33 \%$ & $6,41 \%$ \\
\hline $\begin{array}{l}\text { Ativs imobil, } \\
\text { alug e servs } \\
\text { para firmas. } \\
\text { Saúde, educ, } \\
\text { e servs } \\
\text { sociais. }\end{array}$ & $11,62 \%$ & $12,94 \%$ & $13,09 \%$ & $43,08 \%$ & $18,31 \%$ & $4,78 \%$ & $6,53 \%$ \\
\hline Outras & $19,46 \%$ & $22,79 \%$ & $12,73 \%$ & $35,39 \%$ & $7,78 \%$ & $1,85 \%$ & $8,93 \%$ \\
\hline
\end{tabular}

Fonte: (IBGE; ECINF, 2003) - Elaboração própria.

Nota-se que a atividade de construção civil é a única atividade que possui mais de $50 \%$ de seus empregados com escolaridade inferior ao $1^{\circ}$ grau, ao passo que trabalhadores das atividades imobiliárias, aluguéis e serviços prestados às empresas são o único grupo que mantém mais de 7\% de seus empregados possuindo nível superior completo. Nesse grupo de atividade, também observa-se que a maior parte de seus empregados possuem o $2^{\circ}$ grau e o superior incompleto. Nenhum outro grupo de atividades possui mais de 5\% de seus empregados com nível superior completo. Outro destaque da tabela 5 é o grupo de atividades de saúde, educação e serviços sociais que possui $53,48 \%$ de seus empregados possuindo educação relativa ao $2^{\circ}$ grau. 
A Tabela 6 mostra que o fato de um empreendimento ter mais de um empregado não implica, necessariamente, que todos seus empregados tenham ou todos não tenham carteira de trabalho:

Tabela 6 - Percentual do número de carteira assinada por número de trabalhadores na firma

\begin{tabular}{cccccccc}
\hline \multirow{2}{*}{$\begin{array}{c}\text { no empregados } \\
\text { da firma }\end{array}$} & $\mathbf{8}$ & $\mathbf{8}$ - carteira de trabalho \\
\cline { 2 - 8 } & $\mathbf{0}$ & $\mathbf{1}$ & $\mathbf{2}$ & $\mathbf{3}$ & $\mathbf{4}$ & $\mathbf{5}$ & Total \\
\hline $\mathbf{1}$ & 75,40 & 24,60 & 0 & 0 & 0 & 0 & $\mathbf{1 0 0}$ \\
$\mathbf{2}$ & 57,95 & 8,52 & 33,53 & 0 & 0 & 0 & $\mathbf{1 0 0}$ \\
$\mathbf{3}$ & 45,74 & 5,85 & 8,54 & 39,88 & 0 & 0 & $\mathbf{1 0 0}$ \\
$\mathbf{4}$ & 37,56 & 4,22 & 3,16 & 10 & 45,06 & 0 & $\mathbf{1 0 0}$ \\
$\mathbf{5}$ & 30,09 & 13,81 & 4,12 & 0,83 & 4,03 & 47,12 & $\mathbf{1 0 0}$ \\
\hline Total & $\mathbf{6 4 , 9 5}$ & $\mathbf{1 7 , 7 5}$ & $\mathbf{8 , 3 7}$ & $\mathbf{4 , 7 3}$ & $\mathbf{2 , 4 9}$ & $\mathbf{1 , 7 2}$ & $\mathbf{1 0 0}$ \\
\hline
\end{tabular}

Fonte: (IBGE; ECINF, 2003) - Elaboração própria.

De acordo com a Tabela 6 acima, observa-se que à medida que aumenta-se o número de empregados, aumenta a chance de todos os empregados possuírem carteira de trabalho. Mais especificamente, das firmas com apenas um empregado $\stackrel{13}{,} 75,4 \%$ delas possuem zero carteira de trabalho, ou seja, possuem zero empregado com carteira de trabalho. Por outro lado, $24,6 \%$ das firmas com um empregado possuem uma carteira de trabalho, isto é, possuem um (ou $100 \%$ nesse caso) empregado formal. Esse modo de analisar se estende às firmas com dois, três, quatro e cinco empregados.

A Tabela 6 mostra também que, com relação às firmas com quatro ou cinco empregados, há um maior percentual dessas firmas com o total de seus empregados formalizados do que todos não formalizados. Entretanto, em nenhuma das faixas de tamanho de firmas observamos mais de $50 \%$ das firmas com todos os empregados formalizados, ou seja, nenhum número da diagonal principal da Tabela 6 apresenta número maior que 50\%.

\footnotetext{
${ }^{13}$ A condição para ser empregador é que o empreendimento econômico deste empregador tenha ao menos um empregado. Caso não tivesse, o proprietário da firma não seria um empregador, e sim, um conta-própria.
} 
A seguir, indicamos a média de outras variáveis explicativas e seus respectivos desvios-padrão com dados amostrais, no banco de trabalhadores e no banco de firmas. Essas variáveis utilizadas para analisar a chance do empregado ter ou não carteira assinada já foram sumariamente apresentadas anteriormente e estão sintetizadas na tabela abaixo:

Tabela 7 - Média e desvio padrão de algumas variáveis utilizadas na análise descritiva

\begin{tabular}{c|c|c|c}
\hline Variáveis & Descrição & $\begin{array}{c}\text { Média do } \\
\text { banco de } \\
\text { empregados }\end{array}$ & $\begin{array}{c}\text { Média do } \\
\text { banco de } \\
\text { firmas }\end{array}$ \\
\hline
\end{tabular}

Variável dependente de interesse

\begin{tabular}{|c|c|c|c|}
\hline Carteira & $1=$ possui carteira de trabalho assinada & $40,02 \%$ & ------ \\
\hline \multicolumn{4}{|c|}{ Variável potencialmente endógena } \\
\hline Licença & $1=$ possui licença & $68,63 \%$ & $63,17 \%$ \\
\hline \multicolumn{4}{|c|}{ Características do empregado } \\
\hline Parentes & $1=$ possui parentesco com empregados & $23,06 \%$ & $26,84 \%$ \\
\hline Sexo & $1=$ masculino & $58,06 \%$ & $57,21 \%$ \\
\hline Idade & Idade & $\begin{array}{l}28,24 \\
(9,57)\end{array}$ & $\begin{array}{l}27,91 \\
(8,53)\end{array}$ \\
\hline Idade2 & Idade ao quadrado & $\begin{array}{c}889,18 \\
(676,03)\end{array}$ & $\begin{array}{l}871,44 \\
(871,44)\end{array}$ \\
\hline Educ1 & $\begin{array}{l}1=\text { sem instrução; lê e escreve; } 1^{\circ} \text { grau } \\
\text { incompleto }\end{array}$ & $29,21 \%$ & $30,30 \%$ \\
\hline Educ2 & $1=1^{\circ}$ grau & $16,68 \%$ & $16,01 \%$ \\
\hline Educ3 & $1=2^{\circ}$ grau incompleto & $14,96 \%$ & $15,37 \%$ \\
\hline Educ4 & $1=2^{\circ} \mathrm{grau}$ & $32,68 \%$ & $32,25 \%$ \\
\hline Educ5 & $1=$ superior incompleto & $4,05 \%$ & $3,94 \%$ \\
\hline Educ6 & $1=$ superior completo & $2,43 \%$ & $2,13 \%$ \\
\hline
\end{tabular}

\section{Características do proprietário (empregador)}

\begin{tabular}{llcc} 
Educ1p & $1=$ sem instrução, lê e escreve; $1^{\circ}$ grau & $21,32 \%$ & $23,68 \%$ \\
Educ2p & incompleto & $9,97 \%$ & $11,24 \%$ \\
Educ3p & $1=1^{\circ}$ grau & $7,74 \%$ & $7,55 \%$ \\
Educ4p & $1=2^{\circ}$ grau incompleto & $31,81 \%$ & $30,88 \%$ \\
Educ5p & $1=2^{\circ}$ grau & $8,77 \%$ & $7,46 \%$ \\
Educ6p & $1=$ superior incompleto & $20,39 \%$ & $19,20 \%$ \\
\hline
\end{tabular}

\section{Características da firma}

K_prop

Outr job

Semprefora_Dom

Vend_gov

Subcontr_princ

Registro1
$1=$ utiliza algum tipo de recurso próprio apenas como principal origem do capital necessário para abrir o negócio.

1 = firmas cujo proprietário tem outro trabalho

$1=$ unidade econômica fora do domicílio em que reside

$1=$ venda de produtos para grandes firmas ou ao governo

1= unidade econômica que trabalhava exclusiva ou principalmente por encomenda ou subcontratação.

$1=$ firma que registra as contas do negócio
$69,29 \%$

$68,24 \%$

$12,94 \%$

$13,21 \%$

$79,33 \%$

$77,65 \%$

$10,09 \%$

$8,49 \%$

$18,33 \%$

$16,93 \%$

$85,94 \%$

$82,42 \%$ 
continuação

\begin{tabular}{|c|c|c|c|}
\hline Variáveis & Descrição & $\begin{array}{l}\text { Média do } \\
\text { banco de } \\
\text { empregados }\end{array}$ & $\begin{array}{l}\text { Média do } \\
\text { banco de } \\
\text { firmas }\end{array}$ \\
\hline \multicolumn{4}{|c|}{ Faturamento mensal da firma } \\
\hline Microemp & \multirow{2}{*}{$\begin{array}{l}1=\text { firma com receita } \leq 10 \text { mil reais } / \text { mês } \\
1=\text { firma com receita }>10 \text { mil reais/ mês e } \leq 100 \\
\text { mil reais/ mês }\end{array}$} & $74,94 \%$ & $82,16 \%$ \\
\hline Pequemp & & $25,06 \%$ & $17,84 \%$ \\
\hline \multicolumn{4}{|c|}{ Patrimônio da firma } \\
\hline Patr_peq & $1=$ patrimônio $\leq \mathrm{R} \$ 1 \mathrm{mil}$ & $31,43 \%$ & $41,85 \%$ \\
\hline Patr_méd & $1=$ patrimônio $\geq \mathrm{R} \$ 1$ mil $\mathrm{e} \leq \mathrm{R} \$ 10 \mathrm{mil}$ & $33,85 \%$ & $32,50 \%$ \\
\hline Patr_gde & $1=$ patrimônio $>\mathrm{R} \$ 10 \mathrm{mil}$ & $34,72 \%$ & $25,66 \%$ \\
\hline \multicolumn{4}{|c|}{ Regiões geográficas das firmas } \\
\hline Se_comsp & Dummy de região sudeste & $17,10 \%$ & $17,10 \%$ \\
\hline $\mathrm{S}^{-}+a^{-}$ & Dummy de região sul & $16,46 \%$ & $15,95 \%$ \\
\hline Co & Dummy de região centro - oeste & $18,44 \%$ & $17,96 \%$ \\
\hline $\mathrm{N}$ & Dummy de região norte & $14,96 \%$ & $15,95 \%$ \\
\hline $\mathrm{NE}$ & Dummy de região nordeste & $33,05 \%$ & $33,02 \%$ \\
\hline \multicolumn{4}{|c|}{ Grupos de atividade econômicas das firmas } \\
\hline Ind, Transfor e extrat & $1=$ ind de transf e extrativa & $11,48 \%$ & $10,73 \%$ \\
\hline Construc civil & $1=$ construção civil & $7,34 \%$ & $8,05 \%$ \\
\hline Comérc e reparação & $1=$ comércio e reparação & $34,00 \%$ & $33,80 \%$ \\
\hline Alimen e serv, alojam, & $1=$ Serv, de alojamento e alim & $11,29 \%$ & $11,30 \%$ \\
\hline Transp, armaz e comunic & $1=$ Transp, armazenagem, e comunicações & $5,73 \%$ & $6,55 \%$ \\
\hline $\begin{array}{l}\text { Ativs imobil, alug e servs } \\
\text { para firmas }\end{array}$ & $1=$ ativs imob, alug e serv prestado às empresas & $8,59 \%$ & $8,11 \%$ \\
\hline Saúde, educ, e servs sociais & 1= Educ, saúde e servs sociais & $10,46 \%$ & $10,15 \%$ \\
\hline Outras & $\begin{array}{l}1=\text { outros servs coletivos, sociais e pessoais e } \\
\text { outras atividades }\end{array}$ & $11,12 \%$ & $11,32 \%$ \\
\hline \multicolumn{4}{|c|}{ Ano de criação das firmas } \\
\hline Ano95 & $1=$ criação da firma entre nov.1994 e out.1995 & $5,28 \%$ & $4,86 \%$ \\
\hline Ano96 & $1=$ criação da firma entre nov.1995 e out.1996 & $10,03 \%$ & $9,55 \%$ \\
\hline Ano97 & $1=$ criação da firma entre nov.1996 e out.1997 & $8,08 \%$ & $7,90 \%$ \\
\hline Ano98 & $1=$ criação da firma entre nov. 1997 e out. 1998 & $10,86 \%$ & $10,79 \%$ \\
\hline Ano99 & $1=$ criação da firma entre nov.1998 e out.1999 & $11,72 \%$ & $10,82 \%$ \\
\hline Ano 2000 & $1=$ criação da firma entre nov. 1999 e out. 2000 & $12,16 \%$ & $12,62 \%$ \\
\hline Ano2001 & $1=$ criação da firma entre nov. 2000 e out. 2001 & $14,25 \%$ & $14,45 \%$ \\
\hline Ano2002 & $1=$ criação da firma entre nov.2001 e out.2002 & $15,48 \%$ & $15,48 \%$ \\
\hline Ano2003 & $1=$ criação da firma entre nov.2002 e out.2003 & $12,14 \%$ & $13,51 \%$ \\
\hline Tratamento & $1=$ firmas que podem aderir ao SIMPLES & $68,28 \%$ & $67,94 \%$ \\
\hline Obs válidas & & 6252 & 3391 \\
\hline
\end{tabular}

Fonte: (IBGE; ECINF, 2003) - Elaboração própria.

Da Tabela 7, a idéia de identificar características de pequenas unidades econômicas e dos empregados destas unidades é dimensionar suas influências na geração de postos de trabalho formais. As variáveis e a parte descritiva da Tabela 7 já foram apresentadas 
sumariamente na seção 3.2.1, o que dispensa suas apresentações. Abaixo, seguem alguns comentários sobre as variáveis que ainda não foram analisadas.

Analisando o banco de trabalhadores, constata-se pela dummy carteira que o número de empregados com carteira assinada é menor que o número de empregados sem carteira, e representa cerca de $40 \%$. Quanto às firmas, observando a variável dummy licença, cerca de $68,63 \%$ dos empregados trabalham em firmas com licença. Em relação à dummy parentesco com o empregador, apenas cerca de $23,06 \%$ dos empregados tinham relação de parentesco com o proprietário. Quanto a dummy sexo (homem), verificou-se que os homens constituem $58,06 \%$ da massa trabalhadora. Para a variável idade do empregado, encontrou-se uma média de quase 28 anos de idade, com um desvio padrão de 9,57 anos.

Em relação à dummy "k_prop" indica que quase $70 \%$ dos empregados trabalham em firmas que usam capital prórpio como principal meio para abrirem seus negócios. "Outr_job" mostra que quase $13 \%$ dos empregados trabalham para empregadores que possuem um segundo emprego. "Semprefora_Dom" mostra que mais de 79\% dos empregados trabalham em firmas localizadas fora do domicílio do proprietário. "Vend_gov", por sua vez, mostra que apenas $10 \%$ dos empregados trabalham em firmas que vendem produtos para grandes empresas ou ao governo. "Subcontr_princ" indica que firmas que trabalham com subcontratação possuem cerca de $18 \%$ dos empregados da amostra. "Registro1" mostra que quase $86 \%$ dos empregados trabalham para firmas que fazem algum tipo de registro das contas das negociações

Quanto à receita mensal (em outubro de 2003), fracionada entre as dummies "microemp" - firmas com receita até 10 mil reais por mês - e "pequemp" - firmas com receita acima de 10 mil reais por mês e inferior a 100 mil por mês ${ }^{14}$ - cerca de 74,94 \% são

\footnotetext{
${ }^{14}$ Pela lei 9.317/96, conhecida como SIMPLES, podem aderir à lei firmas com faturamento anual de até 1,2 milhão de reais, além de não poder constituir uma atividade vetada. Como a ECINF 2003 fornece apenas receita mensal em out.2003, neste trabalho optou-se por dividir R\$120 mil (receita anual máxima auferida por uma
} 
empregados de microempresas e o restante $(25,06 \%)$ de pequenas empresas, indicando que a grande maioria dos empregados das unidades econômicas descritas são as que auferem, em média, receita anual de até 120 mil reais, que equivalem a 10 mil reais mensais. Firmas com receita superior a essa receita foram excluídas da análise, pois não seriam enquadradas como MPEs. Com relação ao patrimônio, medido pelas dummies "firm_peq", "firm_med", e “firm_gde”, as médias são semelhantes, dada a divisão igualitária em percentis realizada, como já foi mencionado na seção 3.2.1.

Quanto ao conjunto de dummies que captam o ano de criação da firma, não há muita variação entre os anos, com exceção de “ano95" e "ano97”, que indicam menos empregados que trabalham em firmas criadas nesses anos, se comparado com firmas criadas nos outros anos. Por fim, a dummy tratamento indica que $68,28 \%$ dos empregados trabalham em firmas abrangidas pela lei do SIMPLES. A média dos percentuais de ocorrência das variáveis no banco de firmas acima não mudam muito em relação ao banco de trabalhadores. A interpretação, porém, é que os percentuais das variáveis não se referem aos empregados das firmas, e sim às firmas.

\subsection{RESULTADOS}

$\mathrm{Na}$ Tabela $8 \mathrm{a}$ e 8b, estão expressos os coeficientes (ou efeitos marginais) das variáveis apresentadas na descrição das estatísticas, bem como o desvio-padrão do primeiro e do segundo estágio da regressão, respectivamente. Fazem-se comentários breves sobre o $1^{\circ}$ estágio da regressão, logo abaixo. Comentários adicionais são feitos juntamente com os resultados do $2^{\circ}$ estágio, para melhor comparação de alguns resultados.

pessoa jurídica que a classifica como microempresa) e $\mathrm{R} \$ 1,2$ milhão (receita anual máxima auferida por uma pessoa jurídica que a classifica como pequena empresa) por 12 meses. 
Restringindo-se apenas aos resultados para a regressão com filtro do $1^{\circ}$ estágio, observa-se que a variável "treat", utilizada como variável instrumental, tem efeito significativo a $5 \%$ e positivo de 18,37 p.p. na probabilidade da firma possuir licença municipal e/ou estadual para exercer suas atividades. Das demais variáveis, apresentaram resultado significativo ao menos a 10\%: "sexo" do empregado, indicando que firmas com empregados homens apresentam impacto negativo na probabilidade da firma ter licença; “educ4p", "educ5p", e "educ6p", que apresentaram sinal positivo. Isso indica que firmas com empregadores que possuem $2^{\circ}$ grau (“educ4p"), superior incompleto (“educ6p") e instrução superior ("educ6p") aumentam a probabilidade da firma ter licença, em relação a um empregador com $1^{\circ}$ grau incompleto; "semprefora_dom", sinalizando que firmas localizadas fora do domicílio em que reside seu proprietário, aumentam a chance de terem licença; "subcontr_princ" aponta que unidades econômicas que trabalham exclusivamente ou principalmente com encomenda ou subcontratação diminuem a probabilidade de ter licença; "registro1", expressando que firmas que registram suas contas aumentam a chance de possui licença ; "patr_méd", que indica que têm mais chance de ter licença, as firmas com patrimônio intermediário, em relação às firmas com patrimônio pequeno; "s" e "co", que apontam que firmas localizadas nas regiões sul e centro-oeste aumentam a chance da firma ter licença, do que em relação à região sudeste. As últimas variáveis significativas foram "transfor" e "saúde", indicando que firmas cuja atividade são a "indústria de transformação e extrativa" e "educação, saúde e serviços sociais", respectivamente, diminuem a probabilidade de ter licença, em relação às firmas cuja atividade sejam "transporte, armazenagem e comunicação".

No caso da regressão sem uso de filtro, enfocando apenas a variável "treat", observase que o seu efeito marginal é significativo também, assim como a regressão com filtro, porém, sua magnitude é menor. 
Tabela 8a - Probabilidade de ter licença municipal e/ou estadual (ponderando por peso 5 )

Variável dependente: Licença municipal e / ou estadual 2003

Mínimos Quadrados em Dois Estágios (MQ2E) $\rightarrow 1^{\circ}$ estágio da regressão

\begin{tabular}{|c|c|c|c|c|}
\hline \multirow{2}{*}{ Variáveis } & \multicolumn{2}{|c|}{$\begin{array}{c}(1) \\
M Q 2 E(\text { equação reduzida })-\text { amostra } \\
\text { total }\end{array}$} & \multicolumn{2}{|c|}{$\begin{array}{c}\text { MQ2E (equação reduzida) }- \text { filtrado p/ } \\
\text { ano95 e ano96 }\end{array}$} \\
\hline & Coeficiente & $\begin{array}{c}\text { Desvio- padrão } \\
\text { robusto }\end{array}$ & Coeficiente & $\begin{array}{c}\text { Desvio-padrão } \\
\text { robusto }\end{array}$ \\
\hline Treat & $0,1025^{\star}$ & 0,0399 & $0,1837^{\star *}$ & 0,0799 \\
\hline Parentes & 0,0079 & 0,0340 & $-0,008$ & 0,0657 \\
\hline Sexo & $-0,0305$ & 0,0285 & $-0,1317^{* *}$ & 0,0643 \\
\hline Idade & $-0,006$ & 0,0060 & $-0,0073$ & 0,0098 \\
\hline idade2 & 3,75E-05 & 7,98E-05 & 0,0000 & 0,0000 \\
\hline educ2 & 0,0332 & 0,0415 & 0,1159 & 0,0873 \\
\hline educ3 & 0,0536 & 0,0426 & 0,081 & 0,0927 \\
\hline educ4 & 0,0432 & 0,0423 & $-0,0374$ & 0,0862 \\
\hline educ5 & 0,0666 & 0,0786 & $-0,0579$ & 0,1596 \\
\hline educ6 & $0,2771^{*}$ & 0,0697 & 0,2273 & 0,1636 \\
\hline educ2p & $-0,0482$ & 0,0438 & 0,0072 & 0,1060 \\
\hline educ3p & 0,0511 & 0,0568 & $-0,1344$ & 0,1423 \\
\hline educ $4 p$ & $0,1035^{\star}$ & 0,0373 & $0,2005^{*}$ & 0,0729 \\
\hline educ5p & $0,1600^{*}$ & 0,0625 & $0,1721^{* * *}$ & 0,1062 \\
\hline educ6p & $0,2054^{*}$ & 0,0522 & $0,2702^{*}$ & 0,0860 \\
\hline k_prop & 0,0306 & 0,0268 & 0,0292 & 0,0590 \\
\hline outr_job & 0,0579 & 0,0395 & 0,0502 & 0,0787 \\
\hline Semprefora_dom & $0,1597^{*}$ & 0,0383 & $0,1568^{* *}$ & 0,0708 \\
\hline vend_gov & $-0,0248$ & 0,0576 & 0,1264 & 0,0951 \\
\hline subcontr_princ & $-0,0937^{*}$ & 0,0358 & $-0,1923^{*}$ & 0,0599 \\
\hline Registro1 & $0,2066^{*}$ & 0,0352 & $0,1567^{* * *}$ & 0,0810 \\
\hline patr_med & $0,1751^{*}$ & 0,0357 & $0,1375^{\star * *}$ & 0,0704 \\
\hline patr_gde & $0,2267^{*}$ & 0,0428 & 0,0996 & 0,0783 \\
\hline $\mathrm{S}$ & $0,1370^{*}$ & 0,0331 & $0,1797^{\star *}$ & 0,0755 \\
\hline Co & $0,0890^{*}$ & 0,0328 & $0,1205^{\star \star *}$ & 0,0630 \\
\hline $\mathrm{N}$ & 0,0344 & 0,0393 & 0,0033 & 0,0897 \\
\hline $\mathrm{Ne}$ & $-0,0469$ & 0,0319 & $-0,0374$ & 0,0746 \\
\hline Transfor & $-0,1610^{*}$ & 0,0593 & $-0,2992^{* * *}$ & 0,1637 \\
\hline Construc & $-0,2423^{*}$ & 0,0616 & $-0,2538$ & 0,1699 \\
\hline Comercio & $-0,0778$ & 0,0531 & $-0,1906$ & 0,1565 \\
\hline Alimenta & $-0,0197$ & 0,0605 & $-0,1357$ & 0,1710 \\
\hline Imobilia & $-0,0462$ & 0,0662 & $-0,1844$ & 0,1725 \\
\hline Saúde & $-0,0793$ & 0,0727 & $-0,3773^{* * *}$ & 0,1942 \\
\hline Outras & $-0,0472$ & 0,0625 & $-0,1637$ & 0,1710 \\
\hline pequemp & 0,0147 & 0,0367 & 0,0961 & 0,0665 \\
\hline ano95 & $0,1006^{* * *}$ & 0,0600 & (dropped) & \\
\hline ano96 & $0,0881^{* * *}$ & 0,0466 & $-0,0357$ & 0,0534 \\
\hline ano97 & $0,1419^{*}$ & 0,0476 & (dropped) & \\
\hline ano98 & 0,0437 & 0,0515 & (dropped) & \\
\hline ano99 & 0,0658 & 0,0494 & (dropped) & \\
\hline
\end{tabular}

${ }^{15}$ A ponderação, como foi mencionado anteriormente, é a das firmas. 
Variável dependente: Licença municipal e / ou estadual 2003

Mínimos Quadrados em Dois Estágios (MQ2E) $\rightarrow 1^{\circ}$ estágio da regressão

\begin{tabular}{|c|c|c|c|c|}
\hline \multirow{2}{*}{ Variáveis } & \multicolumn{2}{|c|}{$\begin{array}{c}(1) \\
M Q 2 E(e q u a c ̧ \tilde{a} o \text { reduzida })-\text { amostra } \\
\text { total }\end{array}$} & \multicolumn{2}{|c|}{$\begin{array}{c}(2) \\
M Q 2 E(\text { equação reduzida) })-\text { filtrado p/ } \\
\text { ano95 e ano } 96\end{array}$} \\
\hline & Coeficiente & $\begin{array}{c}\text { Desvio- padrão } \\
\text { robusto }\end{array}$ & Coeficiente & $\begin{array}{c}\text { Desvio-padrão } \\
\text { robusto }\end{array}$ \\
\hline $\begin{array}{l}\text { ano2001 } \\
\text { ano2002 } \\
\text { ano2003 } \\
\text { cons }\end{array}$ & $\begin{array}{c}-0,0036 \\
0,0179 \\
-0,0624 \\
0,2014\end{array}$ & $\begin{array}{l}0,0491 \\
0,0481 \\
0,0454 \\
0,1265\end{array}$ & $\begin{array}{c}\text { (dropped) } \\
\text { (dropped) } \\
\text { (dropped) } \\
0,5412^{\star \star}\end{array}$ & 0,3032 \\
\hline $\begin{array}{l}\text { № de obs } \\
\text { Prob > F } \\
\text { R2 } \\
\text { Root MSE }\end{array}$ & $\begin{array}{c}3391 \\
0,0000 \\
0,3495 \\
0,3943\end{array}$ & & $\begin{array}{c}489 \\
0,0000 \\
0,4606 \\
0,3665\end{array}$ & \\
\hline
\end{tabular}

* estatisticamente signif a $1 \%$

** estatisticamente signif a $5 \%$

*** estatisticamente signif a $10 \%$

( ) estatisticamente não significante

Fonte: (IBGE; ECINF, 2003) - Elaboração própria.

$\mathrm{Na}$ tabela 8 b, são apresentadas as três estimações para verificar a probabilidade de empregados de micro e pequenas empresas possuírem carteira de trabalho assinada. O primeiro modelo é uma estimação por Mínimos Quadrados Ordinários (MQO), diretamente, ignorando a possibilidade de endogeneidade entre os indicadores, sem uso de filtro (ou seja, de 1994 em diante), mas controlando para anos de 1995 à 2003. O segundo modelo é uma estimação por MQ2E, sem uso de filtro e controlando para os anos de criação de 1995 à 2003. O terceiro modelo também é por MQ2E, mas usa-se filtro apenas para firmas criadas em 1995 e 1996, e controlando-se para esses dois anos. Quando parecer necessário, retomam-se alguns resultados do $1^{\mathrm{o}}$ estágio, para fazer um contraponto com os resultados obtidos no $2^{\mathrm{o}}$ estágio.

Em princípio, esperava-se que a dummy licença estimada - "licença" - que indica firmas estimadas com licença municipal ou estadual, apresente sinal positivo em relação à probabilidade de seus trabalhadores terem carteira assinada. $\mathrm{Na}$ Tabela $8 \mathrm{~b}^{\frac{16}{6}}$, a variável

\footnotetext{
${ }^{16}$ Os comentários dos resultados abaixo, quando não especificarem a estimação, referem-se à estimação com filtro e ao $2^{\circ}$ estágio, ou seja, ao banco de trabalhadores.
} 
"licença", que internaliza os efeitos da variável instrumental é significante a $10 \%$, ao analisarmos apenas as firmas que foram antes do SIMPLES. Isso indica que o fato da firma possuir licença, em relação a não possuir licença, aumenta a probabilidade de o trabalhador ser formal também, a um nível de significância estatística de $10 \%$.

Em relação à estimação sem filtro, observa-se que a variável "licença" estimada não foi estatisticamente significativa, indicando que não é possível dizer que firmas informais empregam mais trabalhadores informais. Quanto à regressão por MQO, observa-se que a variável "licença" teve coeficiente com magnitude intermediária entre o modelo de MQ2E sem filtro e com filtro, além de ser significativa.

Pode-se notar que, no $1^{\circ}$ estágio, a variável "treat", usada para corrigir a endogeneidade, apresentou sinal positivo e significativo em ambas estimações da Tabela 8 a, mas com magnitudes distintas. Quando não é usado filtro, encontrou-se um coeficiente de 0,1025 e significante a $1 \%$. Com o uso do filtro, considerado o modo mais correto nessa dissertação, a magnitude do coeficiente foi de 0,1837 e significante a 5\%. Ou seja, com uso de filtro, a variável "treat" apresentou um resultado mais expressivo na probabilidade da firma ter licença do que quando o uso do filtro é ignorado. Nos dois estágios, a estimação com filtro foi a que apresentou resultados positivos e significativos para "treat" e licença".

Vejamos agora as demais variáveis explicativas. Quanto ao sinal esperado para o coeficiente da idade, acreditava-se que este seria positivo e da idade 2 negativo, de forma a captar uma relação não linear em forma de U invertido entre a variável binária dependente carteira (que é 1 para ter carteira de trabalho assinada) e idade, pois supõe-se ser mais difícil conseguir um emprego formal (com carteira assinada) com uma idade mais avançada do que a média. A regressão mostra que o termo "idade" é positivo e significativo a $10 \%$, enquanto “idade2” é negativo e significantivo a 5\%, o que confirma a relação de U invertido descrita anteriormente. Isso significa que a probabilidade de possuir carteira aumenta com a idade 
inicialmente, ainda que de modo tímido, porém, após certo ponto, ocorre inversão nessa tendência, ou seja, a probabilidade de possuir carteira assinada para um empregado bem jovem, assim como para um empregado idoso indicam diferenças estatisticamente relevantes. Entretanto, em relação ao efeito marginal da variável idade, deve-se lembrar apenas que seu cálculo não é observado diretamente da tabela acima ${ }^{\square}$. Fazendo o cálculo, é cerca de 22,86 p.p.

Em relação ao patrimônio, esperava-se que as dummies que o representam tenham sinal positivo, porque quanto maior o patrimônio da firma, a chance da firma arriscar em contratar um trabalhador irregular é provavelmente menor. A idéia é que, quanto maior a firma, a tendência é um maior enforcement, uma vez que a firma se torna mais visada por fiscais do trabalho. Mas as dummies usadas para patrimônio não confirmam nossa expectativa, apresentando relação positiva em relação à probabilidade do trabalhador ser formalizado, mas não significativa. Entretanto, pela ótica da firma, o resultado foi significativo no $1^{\text {o }}$ estágio para "patr_méd". Assim, a dummy, para empreendimentos que possuem patrimônio entre $1 \mathrm{mil}$ reais e 10 mil reais, é responsável por aumentar a probabilidade dos empregados serem formalizados em 13,75 p.p., em relação às firmas com patrimônio avaliado em até 1 mil reais. Esses resultados sugerem que firmas que detêm maior patrimônio avaliado estão mais expostos às malhas da fiscalização, e optam por operarem em situação regular.

Já em relação à receita, a variável "pequemp" indica que firmas com maior receita, maior que dez mil reais e menor igual a 100 mil reais por mês, aumentam a probabilidade de empregados terem carteira de trabalho, em relação àquelas firmas com receita mensal igual ou

\footnotetext{
${ }^{17}$ No caso geral, o efeito marginal de uma variável Xk para um indivíduo i num modelo linear de probabilidade é calculado como: $\partial$ (Xi $\beta$ ) / $\partial \beta$, onde Xi e $\beta$ são vetores $(1 \times K)$ e $(\mathrm{Kx} 1)$, respectivamente. Mas como temos a variável idade e idade ${ }^{2}$, o efeito marginal é, no ponto da média das explicativas: $\partial\left(\beta_{1} \mathrm{x}\right.$ idade $+\beta_{2} \mathrm{x}$ idade $\left.{ }^{2}\right) /$ $\partial$ idade, onde $\beta_{1}$ e $\beta_{2}$ são coeficientes estimados via MQ2E para as variáveis idade e idade².
} 
inferior a dez mil reais. Entretanto, quando a unidade de observação é a firma, a probabilidade de ter licença independe da receita, de acordo com o $1^{\circ}$ estágio.

Quanto a variável binária para parentesco, esperava-se que alguma relação de familiaridade influenciasse na chance de ter vínculo formal de emprego, ainda que não fosse um resultado evidente. No caso da dummy parentesco, nota-se que, como era esperado, possuir ligação de parentesco com o proprietário da firma favorece na probabilidade de ser um empregado formal, em relação aos empregados sem qualquer ligação familiar, porém o coeficiente é pequeno (cerca de 2,57 p.p ou 0,0257 pontos na probabilidade) e estatisticamente não significante.

Já quanto à variável qualitativa para sexo masculino, esperava-se que a relação com carteira assinada fosse negativa, uma vez que a participação feminina no mercado de trabalho formal vir aumentando muito recentemente, em relação aos homens, mesmo em pequenas firmas. O fato de mais mulheres estarem se tornando formais, enquanto homens informais, tem sido perceptível entre 1992 e 2001 (HENLEY; ARABSHEIBANI; CARNEIRO, 2006).

A variável é não significativa no $2^{\circ}$ estágio, indicando que gênero não influi na probabilidade de ter carteira de trabalho. Já no $1^{\circ}$ estágio a variável mostrou-se significativa, indicando que firmas com trabalhadores homens diminuem, em relação às mulheres, a probabilidade da firma possuir licença. Possíveis explicações são que a tendência é da evolução da participação feminina no mercado de trabalho nas últimas décadas (SCORZAFAVE; MENEZES-FILHO, 2001). O típico trabalhador do setor formal urbano era homem, trabalhava em período integral em manufatura, era um membro de união comercial e desfrutava de um alto grau de proteção do trabalho e seguridade social. Isso mudou drasticamente e uma distinção clara entre trabalhadores formais e informais não é fácil. Atualmente, o trabalhador típico do setor informal está mais provavelmente no setor de 
serviços, e poderia facilmente ser um trabalhador com um contrato de curta duração (THOMAS, 2002).

Tabela $8 b$ - Probabilidade de ter carteira de trabalho assinada (ponderando por peso ${ }_{8}$ )

Variável dependente: carteira de trabalho assinada em 2003

Método de estimação: Mínimos Quadrados em Dois Estágios (MQ2E) $\rightarrow 2^{\circ}$ estágio da regressão

\begin{tabular}{|c|c|c|c|c|c|c|c|}
\hline \multirow[t]{2}{*}{ Variáveis } & \multicolumn{2}{|c|}{$\begin{array}{c}\text { (1) } \\
M Q O-\text { amostra total }\end{array}$} & \multicolumn{2}{|c|}{$\begin{array}{c}\text { (2) } \\
\text { MQ2E (equação } \\
\text { principal) - amostra } \\
\text { total }\end{array}$} & \multicolumn{2}{|c|}{$\begin{array}{c}\text { (3) } \\
\text { MQ2E (equação } \\
\text { principal) - filtrado } \\
\text { p/ano95 e ano96 }\end{array}$} & \multirow{2}{*}{\begin{tabular}{|c} 
(4) \\
Sinais das \\
probabilida \\
des feitas \\
por MQ2E \\
Sinais
\end{tabular}} \\
\hline & Coeficiente & $\begin{array}{l}\text { Desvio- } \\
\text { padrão }\end{array}$ & Coeficiente & $\begin{array}{l}\text { Desvio- } \\
\text { padrão }\end{array}$ & Coeficiente & $\begin{array}{l}\text { Desvio- } \\
\text { padrão }\end{array}$ & \\
\hline Licença & $0,2717^{*}$ & 0,0300 & 0,0833 & 0,2604 & $0,3399^{\star * *}$ & 0,2074 & NS \\
\hline Parentes & $-0,1180^{\star}$ & 0,0240 & $-0,1108^{*}$ & 0,0258 & 0,0257 & 0,0490 & NS \\
\hline Sexo & $-0,059^{*}$ & 0,0223 & $-0,0636^{*}$ & 0,0239 & $-0,0318$ & 0,0444 & NS \\
\hline Idade & $0,0069^{* * *}$ & 0,00370 & $0,0064^{* * *}$ & 0,0039 & $0,0102^{* * *}$ & 0,0055 & + \\
\hline Idade2 & $-8,3 \mathrm{E}-05^{\star \star *}$ & $4,9 \mathrm{E}-05$ & -8,1E-05 & 5,28E-05 & $-0,0001^{* *}$ & 6,53E-05 & NS \\
\hline Educ2 & $0,0628^{* * *}$ & 0,0327 & $0,0730^{* *}$ & 0,0333 & 0,0943 & 0,0671 & NS \\
\hline Educ3 & 0,0008 & 0,0316 & 0,0161 & 0,0348 & $0,1272^{* * *}$ & 0,0739 & NS \\
\hline Educ4 & $0,0756^{*}$ & 0,0290 & $0,0917^{*}$ & 0,0313 & 0,0516 & 0,0580 & NS \\
\hline Educ5 & $-0,065$ & 0,0585 & $-0,0443$ & 0,0579 & $-0,0267$ & 0,1024 & NS \\
\hline Educ6 & $-0,022$ & 0,0632 & 0,0192 & 0,0655 & $-0,1630$ & 0,1066 & NS \\
\hline Educ2p & $-0,036$ & 0,0389 & $-0,0441$ & 0,0400 & 0,0497 & 0,0876 & NS \\
\hline Educ3p & $-0,096^{* *}$ & 0,0425 & $-0,0938^{* *}$ & 0,0462 & $-0,0335$ & 0,1147 & NS \\
\hline Educ4p & 0,0500 & 0,0321 & 0,0723 & 0,0450 & 0,1056 & 0,0835 & NS \\
\hline Educ $5 p$ & 0,0407 & 0,0497 & 0,0509 & 0,0794 & 0,0373 & 0,1411 & NS \\
\hline Educ6p & $0,1996^{*}$ & 0,0449 & $0,2334^{*}$ & 0,0648 & $0,2646^{\star *}$ & 0,1043 & + \\
\hline K_prop & $-0,0237$ & 0,0249 & $-0,0185$ & 0,0286 & $0,1070^{* *}$ & 0,0502 & NS \\
\hline Outr_job & 0,0216 & 0,0394 & 0,0238 & 0,0423 & 0,1009 & 0,0690 & NS \\
\hline Semprefora_ & & & & & & & NS \\
\hline Dom & $0,0953^{*}$ & 0,0263 & $0,1376^{*}$ & 0,0406 & 0,0658 & 0,0667 & \\
\hline Vend_gov & 0,0195 & 0,0415 & 0,0227 & 0,0470 & $-0,0526$ & 0,0821 & NS \\
\hline Subcontr_princ & $-0,0173$ & 0,0269 & $-0,0315$ & 0,0378 & $-0,0033$ & 0,0668 & NS \\
\hline Registro1 & 0,0367 & 0,0284 & 0,0859 & 0,0633 & $0,1044^{* * *}$ & 0,0630 & NS \\
\hline Patr_méd & $0,1423^{*}$ & 0,0294 & $0,1780^{*}$ & 0,0558 & 0,0325 & 0,0684 & NS \\
\hline Patr_gde & $0,1459^{*}$ & 0,0443 & $0,1904^{\star *}$ & 0,0744 & 0,0889 & 0,0996 & NS \\
\hline $\mathrm{S}$ & $0,0847^{* *}$ & 0,0342 & $0,1111^{* *}$ & 0,0447 & $0,1389^{* * *}$ & 0,0817 & + \\
\hline Co & $-0,0604^{* *}$ & 0,0309 & $-0,0452$ & 0,0378 & 0,0300 & 0,0796 & NS \\
\hline $\mathrm{N}$ & $-0,1233^{*}$ & 0,0339 & $-0,1134^{*}$ & 0,0358 & $-0,1425^{\star * *}$ & 0,0810 & - \\
\hline Nordeste & $-0,0842^{*}$ & 0,0281 & $-0,0925^{*}$ & 0,0332 & $-0,1223^{\star * *}$ & 0,0663 & - \\
\hline
\end{tabular}

${ }^{18}$ A ponderação, como foi mencionado anteriormente, é a das firmas. 
Variável dependente: carteira de trabalho assinada em 2003

Método de estimação: Mínimos Quadrados em Dois Estágios (MQ2E) $\rightarrow 2^{\circ}$ estágio da regressão

\begin{tabular}{|c|c|c|c|c|c|c|c|}
\hline \multirow[t]{2}{*}{ Variáveis } & \multicolumn{2}{|c|}{$\begin{array}{c}\text { (1) } \\
M Q O-\text { amostra total }\end{array}$} & \multicolumn{2}{|c|}{$\begin{array}{c}\text { (2) } \\
\text { MQ2E (equação } \\
\text { principal) - amostra } \\
\text { total }\end{array}$} & \multicolumn{2}{|c|}{$\begin{array}{c}\text { (3) } \\
\text { MQ2E (equação } \\
\text { principal) - filtrado } \\
\text { p/ano95 e ano96 }\end{array}$} & \multirow{2}{*}{$\begin{array}{c}\text { (4) } \\
\text { Sinais das } \\
\text { probabilida } \\
\text { des feitas } \\
\text { por MQ2E } \\
\\
\text { Sinais }\end{array}$} \\
\hline & Coeficiente & $\begin{array}{l}\text { Desvio- } \\
\text { padrão }\end{array}$ & Coeficiente & $\begin{array}{l}\text { Desvio- } \\
\text { padrão }\end{array}$ & Coeficiente & $\begin{array}{l}\text { Desvio- } \\
\text { padrão }\end{array}$ & \\
\hline $\begin{array}{l}\text { Ind, Transfor e } \\
\text { extrat }\end{array}$ & $0,1226^{* *}$ & 0,0525 & 0,0970 & 0,0671 & 0,1006 & 0,1460 & NS \\
\hline Construc civil & 0,0617 & 0,0486 & 0,0195 & 0,0853 & $-0,0527$ & 0,1502 & NS \\
\hline $\begin{array}{l}\text { Comérc e } \\
\text { reparação }\end{array}$ & $0,1378^{*}$ & 0,0457 & $0,1300^{* *}$ & 0,0514 & 0,1016 & 0,1408 & NS \\
\hline $\begin{array}{l}\text { Alimen e serv, } \\
\text { alojam, }\end{array}$ & 0,0411 & 0,0506 & 0,0398 & 0,0538 & $-0,1168$ & 0,1461 & NS \\
\hline $\begin{array}{l}\text { Ativs imobil, } \\
\text { alug e serv s } \\
\text { para firmas }\end{array}$ & $0,1372^{* *}$ & 0,0541 & $0,1275^{\star *}$ & 0,0588 & 0,1884 & 0,1486 & NS \\
\hline $\begin{array}{l}\text { Saúde, educ, e } \\
\text { servs sociais }\end{array}$ & 0,0524 & 0,0668 & 0,0246 & 0,0704 & $-0,0068$ & 0,1837 & NS \\
\hline $\begin{array}{l}\text { Outras } \\
\text { pequemp }\end{array}$ & $\begin{array}{l}-0,0406 \\
0.1126^{*}\end{array}$ & 0,0546 & $\begin{array}{l}-0,0382 \\
0,1164^{*}\end{array}$ & 0,0576 & $\begin{array}{l}-0,1268 \\
0,1818^{\star *}\end{array}$ & $\begin{array}{l}0,1460 \\
0,0910\end{array}$ & $\begin{array}{c}\text { NS } \\
+\end{array}$ \\
\hline Ano95 & $\begin{array}{l}0,1126 \\
-0,0280\end{array}$ & $\begin{array}{l}0,0425 \\
0,0590\end{array}$ & $\begin{array}{l}0,1164 \\
-0,0195\end{array}$ & $\begin{array}{l}0,0442 \\
0,0681\end{array}$ & $\begin{array}{l}0,1818 \\
-0,0313\end{array}$ & 0,0463 & $\stackrel{+}{N}$ \\
\hline Ano96 & $-0,0035$ & 0,0497 & 0,0096 & 0,0548 & (dropped) & & \\
\hline Ano97 & 0,0734 & 0,0496 & 0,0857 & 0,0613 & (dropped) & & \\
\hline Ano98 & $-0,0044$ & 0,0510 & $-0,0073$ & 0,0530 & (dropped) & & \\
\hline Ano99 & $-0,0263$ & 0,0468 & $-0,0362$ & 0,0561 & (dropped) & & \\
\hline Ano 2001 & 0,0647 & 0,0448 & 0,0633 & 0,0471 & (dropped) & & \\
\hline Ano 2002 & $-0,0616$ & 0,0418 & $-0,0677$ & 0,0458 & (dropped) & & \\
\hline Ano 2003 & $-0,0797^{\star \star *}$ & 0,0480 & $-0,0930^{\star * *}$ & 0,0518 & (dropped) & & \\
\hline $\begin{array}{l}\text { Número de } \\
\text { observações }\end{array}$ & 6252 & & 6252 & & 957 & & \\
\hline Prob $>$ F & 0,00 & & 0,00 & & 0,00 & & \\
\hline $\mathbf{R 2}$ & 0,3897 & & 0,3434 & & 0,4882 & & \\
\hline Root MSE & 0,3823 & & 0,3966 & & 0,3555 & & \\
\hline
\end{tabular}

* estatisticamente signif a $1 \%$

** estatisticamente signif a $5 \%$

*** estatisticamente signif a $10 \%$

( ) estatisticamente não significante

Fonte: (IBGE; ECINF, 2003) - Elaboração própria.

Todas as variáveis restantes da Tabela $8 \mathrm{~b}$ que faltam fazer comentários são variáveis binárias (dummies), todas com efeitos marginais baixos, de um modo geral. Em relação aos 
sinais dos outros efeitos marginais que foram comentados, além de baixos, não se mostraram todos esperados, considerando as observações feitas anteriormente em relação à licença estimada e ao sexo masculino.

Das variáveis binárias referentes ao nível educacional, tanto do empregado quanto do empregador, todas se mostraram estatisticamente não significantes, exceto a variável "educ3" (empregado com $2^{\circ}$ grau incompleto). Isso significa que para as demais variáveis que captam o nível educacional do empregado, caso um desses indivíduos de um grupo com menor nível de instrução passar para outro grupo de maior instrução, não implicará em variação na probabilidade de apresentar carteira de trabalho assinada.

De modo semelhante, ao analisarmos o nível educacional dos proprietários (empregadores das unidades econômicas analisadas), todas as variáveis educacionais dos proprietários foram estatisticamente não significativas ao menos a $10 \%$ exceto "educ6p" (proprietário com nível educacional superior completo). Assim, proprietários com nível superior de educação, apresentam variação estatisticamente significante na probabilidade de seus trabalhadores terem carteira de trabalho, em relação a proprietários que apresentam apenas o $1^{\mathrm{o}}$ grau incompleto. No caso do banco em que a unidade de observação é a firma, “educ4p" (proprietário com $2^{\circ}$ grau), educ5p" (proprietário com educação superior incompleta) e "educ6p" (proprietário com educação superior) foram significativas. Isso significa que firmas que possuem proprietários com esses níveis de educação aumentam a probabilidade de terem licença. As demais dummies que captam educação foram não significativas.

A possível interpretação decorrente da maior parte das dummies referentes ao nível educacional não serem significativas é que quando se controla para todas outras características, nível de instrução não é tão importante, porque características mais inerentes à firma acabam determinando a probabilidade de ter carteira de trabalho ou mesmo licença. 
Outra possibilidadade para essa ocorrência seria o fato de trabalhadores com maior nível de educação estarem, em anos recentes, mais propensos a trabalhar na informalidade do que trabalhadores com menor nível de educação, tornando a distinção entre mais instruídos e menos instruídos não clara. Recente estudo, analisando econometricamente dados disponíveis pela Pesquisa Nacional por Amostra de Domicílios (PNAD), para o período de 1992 a 2001, também indica que taxas de informalidade estão crescendo rapidamente entre os mais educados. Constata-se ainda que informalidade definida pela carteira de trabalho é menos fortemente associada com menor educação obtida do que em outras duas definições empregadas. Razões pelas quais pessoas do sexo masculino e aqueles com maior nível de educação parecem crescentemente preferir trabalhar sem carteira de trabalho ou "atividade informal" merecem análises adicionais (HENLEY; ARABSHEIBANI; CARNEIRO, 2006).

Em relação à variável que indica se o local de trabalho do empregador é fora do domicílio, investigou-se se o proprietário da firma desenvolvia suas atividades pertinentes ao negócio fora de seu domicílio, mesmo que fosse em outro domicílio, desde que não o dele (os dados obtidos pela Ecinf 2003 evitam que ocorra dupla contagem, como contar duas vezes o mesmo empreendimento ao entrevistar o proprietário e seu sócio, por exemplo). A dummy mostrou-se positiva e não significativa, o que não permite dizer se ter mais proprietários de firmas que fazem negócios fora do domicílio amplia a probabilidade de os trabalhadores dessas firmas serem formalizados. No caso de a unidade de observação ser a firma, encontrou-se no $1^{\circ}$ estágio, a um nível de significância de 5\%, que proprietários que possuem local de trabalho fora do domicílio, aumentam a probabilidade da firma ter licença, do que se as firmas fossem dentro do domicílio. Um motivo que poderia explicar essa situação é que negócios executados fora do domicílio do proprietário são mais expostos à fiscalização.

Sinal oposto é encontrado para o efeito marginal da variável qualitativa vendas ao governo e a grandes empresas, mas seu impacto marginal se mostrou negativo e não 
significativo, nem muito relevante (cerca de - 5,26 p.p.). Já quando é observada a firma, encontrou-se resultado positivo e não significativo. Este efeito marginal era bem esperado que fosse positivo e significativo, ao menos quando se observa a firma, uma vez que De Paula e Scheinkman (2006) verifica que quando uma firma vende ou compra de empresas formais, ela tem mais probabilidade de se tornar formal, assim como aumenta essa tendência à medida que mais vende a grandes empresas e instituições governamentais.

As unidades econômicas que operavam por meio de encomenda ou subcontratação como forma exclusiva ou principal da atividade econômica mostraram uma pequena redução na chance dos empregados obterem carteira de trabalho, porém essa variável mostrou-se estatisticamente não significante também. Esse resultado sugere que as atividades de subcontratação e encomenda, não influem muito na forma empregatícia de seus trabalhadores. Resultado diferente ocorre quando se observa a firma, pois firmas que trabalham com encomenda ou subcontratação como meio exclusivo ou principal de atividade econômica, reduz em cerca de 20 p.p (com nível de significância de 1\%) a probabilidade da firma ter licença. Esse efeito negativo é mais esperado, pois atividades de subcontratação e terceirização são recriações de antigas relações de trabalho, possibilitando maior manobra para informalização do mercado de trabalho (CACCIAMALI; PIRES, 1997).

Já empreendimentos que possuem controle das contas do negócio, representadas pela variável "registro" aumentam em cerca de 10p.p. a chance dos empregados trabalharem formalizadamente, a um nível de significância de $10 \%$. Já no caso da unidade de observação ser a firma, ao mesmo nível de significância, encontrou-se que as firmas que possuem controle das contas do empreendimento aumentam em 15,67 p.p a chance de serem formais.

Em relação às dummies que indicam grupos de atividade, todas as dummies mostraram-se não significativas. Observou-se que, controlando pelas demais características mencionadas detalhadas anteriormente, os empregados de atividades Indústria de 
transformação e extrativa, das atividades comércio e reparação e das atividades imobiliárias, aluguéis e serviços prestados às empresas, aumentam a probabilidade de seus empregados possuírem carteira do que em relação às atividades de transporte, armazenagem e comunicação, mas sem significância estatística. Nas demais atividades os efeitos marginais foram negativos, mas igualmente não significantes. Em relação às firmas, os grupos de atividades da indústria da transformação e extrativa e das atividades de educação, saúde e serviços sociais, apresentaram-se significativos (a 10\%), mas diminuem a probabilidade da firma ter licença, em relação ao grupo de comparação.

Em relação às dummies regionais, infere-se que apenas os empregados da região sul são os que apresentaram maior chance de ter carteira de trabalho assinada, em relação à região sudeste. A região norte e nordeste, por sua vez, apresentaram empregados que trabalham nessa região com probabilidade de ter carteira de trabalho menor do que em relação ao sudeste. Empregados da região centro-oeste tiveram chance maior em apresentar carteira de trabalho, quando comparados aos empregados da região sudeste, entretanto, a região centrooeste não exibiu resultado significante. Já quando a unidade de observação é firma, sul foi a região que apresentou maior probabilidade de encontrar firmas com licença, em relação à região sudeste. As outras dummies de região não foram significativas.

Por fim, uma constatação em comum aos dois estágios do modelo por MQ2E com filtro, na Tabela $8 \mathrm{~b}$, é que o conjunto de variáveis dummies que controlam o período de criação das firmas não apresentam diferença estatística. Isso indica que controlando o período de criação das firmas, não há diferença estatisticamente significativa entre o conjunto dessas dummies, em relação ao ano de comparação, que influencie a probabilidade de formalidade dos empregados ou das firmas. Assim, ainda que firmas representadas pela variável "licença" no segundo estágio seja positiva e significante, o que significa que firmas que se formalizaram aumentam a probabilidade dos empregados terem carteira de trabalho, mas isso independe do 
ano de criação da firma ser 1995 ou 1996. No modelo por MQ2E sem filtro, a única dummy de ano significativa, "ano2003", apresentou sinal negativo. Isso significa que firmas criadas nesse período diminuem a probabilidade dos trabalhadores terem carteira.

Com relação à última coluna da Tabela $8 b$, ela indica que, para o caso das probabilidades de carteira de trabalho, das seis variáveis que foram significativas nas duas estimações, isto é, de MQ2E com filtro e sem filtro, todas apresentaram o mesmo sinal. Isso sugere que, de modo geral, ao considerar apenas as variáveis que importam estatisticamente nas duas regressões mencionadas as variáveis que aumentam a probabilidade de um indivíduo se encontrar formal, ocorrem tanto em firmas criadas de novembro de 1994 à outubro de 2003 (caso das firmas das regressões 1 e 2), quanto em firmas criadas de novembro de 1994 até outubro de 1996 (caso da regressão 3). 


\section{CONSIDERAÇÕES FINAIS}

O objetivo da pesquisa era verificar se micro e pequenas empresas que possuíssem licença municipal e / ou estadual afetam de modo positivo e significativo a probabilidade de seus empregados terem carteira de trabalho assinada.

Para atingir esse objetivo, avaliou-se a probabilidade do empregado ter carteira de trabalho dependendo da licença da firma e características do próprio empregado, da firma em que trabalha e do proprietário da firma. Fizeram-se três estimações, utilizando o modelo de mínimos quadrados ordinários (MQO) e o de mínimos quadrados ordinários em 2 estágios (MQO2E). O modelo de MQO não corrige o problema da variável potencialmente endógena que representa a licença da firma. Quanto ao modelo de MQO2E, corrigindo a endogeneidade, fez-se uma estimação sem uso de filtro e uma com o uso de filtro.

Os resultados no $1^{\circ}$ estágio da regressão sem filtro e com filtro para a variável "treat" apresentaram sinais positivos e estatisticamente significativos ao menos a $5 \%$, na probabilidade da firma ter licença. No $2^{\circ}$ estágio, o resultado não é uniforme, pois há três modelos. O método de MQO, sem corrigir para a endogeneidade, apresentou a variável "licença" positiva e significativa a 1\%. No modelo que usa o método de MQ2E sem utilizar filtro, a variável "licença" mostrou-se positivo e não significante. Já o modelo de MQ2E que faz uso filtro, a variável "licença" teve efeito marginal positivo e significante a $10 \%$ para a probabilidade do empregado ter carteira de trabalho assinada.

Isso indica que os empregados das unidades econômicas que podiam aderir ao SIMPLES apresentaram, para o período de novembro de 1994 a outubro de 1997, em relação às variáveis significativas estatisticamente: 
- Aumento na probabilidade de possuir carteira de trabalho assinada em 0,34 pontos, em relação aos trabalhadores dos empreendimentos econômicos que foram vetados (grupo de controle) do SIMPLES, sendo estatisticamente significativo a $10 \%$.

- Aumento na probabilidade de possuir carteira de trabalho assinada os empregados que fossem mais jovens, que apresentassem $2^{\circ}$ grau incompleto quando comparadas com trabalhadores com $1^{\circ}$ grau incompleto, que fossem empregados de proprietários com nível superior, quando comparados com proprietários com $1^{\circ}$ grau incompleto, que trabalhassem em firmas nas quais o proprietário (empregadores) utiliza apenas recursos próprios como principal origem de capital para abrir seu negócio, que trabalhassem para empregadores que mantenham algum tipo de controle das contas do negócio, que trabalhem preferivelmente em firmas localizadas na região sul da federação brasileira do que na região sudeste e em firmas que auferissem receita mensal superior a dez mil reais do que em relação àquelas que auferissem menos que isso.

Contudo, deve-se considerar que o objetivo do estudo se limitou à observar trabalhadores de MPEs com até cinco empregados, já que essa é uma limitação do questionário da ECINF 2003. Desse modo, sugere-se que, em pesquisas futuras, amostras representativas de outros segmentos da população sejam utilizadas, inclusive analisando diferentes setores de atividade econômica. Além disso, o Supersimples, que aumentou a abrangência da lei do SIMPLES, é uma possibilidade a ser explorada. 


\section{REFERÊNCIAS}

ALMEIDA, R.; CARNEIRO, P. Enforcement of regulation, informal labor and firm performance. Discussion Paper n.1759. Institute for the Study of Labor (IZA), 2005, p.1-32. Disponível em $<$ http:Www.econpapaers.repec.org. Acesso em 21 jul. 2005.

ANGRIST, J; KRUEGUER, A. Instrumental variables and the search for identification: from supply and demand to natural experiments. NBER Working Paper, n.8456, 2001. Disponível em $<$ http://econ-www.mit.edu/faculty/download pdf.php?id=740 . Acesso em 3 set. 2006.

ASEA, P.K. The informal sector: baby or bath water?. Carnegie-Rochester Series on Public Polic, New York, v. 45, p. 369-84, 1996.

BAUM, C. F., SCHAFFER, M. E., STILLMAN, S. Instrumental variables and GMM: Estimation and testing, Working paper n. 545, Boston College Department of Economics, 2002. Disponível em: http://fmwww.bc.edu/ec-p/WP545.pdf. Acesso em 3 set. 2006.

BRASIL. Decreto Lei $\mathrm{n}^{\circ} 9.317$, de 05 de dezembro de 1996. Dispõe sobre o regime tributário das microempresas e das empresas de pequeno porte, institui o Sistema Integrado de Pagamento de Impostos e Contribuições das Microempresas e das Empresas de Pequeno Porte (SIMPLES) e dá outras providências. Diário Oficial da República Federativa do Brasil, Brasília, p.25973/7, 06 de dezembro de 1996.

CACCIAMALI, M. C. Setor informal urbano e formas de participação na produção.

Série ensaios Econômicos, n.26, IPE/USP, São Paulo, 1983.

CACCIAMALI, M. C.; PIRES, J. M. Perspectivas das micro e pequenas empresas ante o contexto atual da economia mundial e brasileira. Estudos econômicos, São Paulo, n.27, p.85$115,1997$.

CAPP, J.; ELSTRODT, H.P.; JONES, J.R. Reining in Brazil's informal economy. The McKinsey Quarterly, n.1, 2004 Disponível em http://www.mckinseyquarterly.com. Acesso em: 6 set.2006.

CARDOSO JR., C.; FERNANDES, S. A informalidade revisitada: evolução nos últimos 20 anos e mais uma hipótese para pesquisa. Rio de Janeiro. Boletim de Mercado de Trabalho.Conjuntura e Análise,n. 14. IPEA, p. 39-49, 2000.

CERVO, A. L; BERVIAN, P. A. Métodos e técnicas científicas. In: CERVO, A. L; BERVIAN, P. A. Metodologia científica, 5 ed. São Paulo: Pearson Prentice Hall, 2002, cap. 2, p.23-50.

DE PAULA, A.; SCHEINKMAN, J. A. The informal sector. University of Pennsylvania, 2006. (Mimeografado)

DEDECCA, C.S.; BALTAR, P. E. A. Mercado de trabalho e informalidade nos anos 90. Estudos econômicos, São Paulo, n.27, p. 65-84, 1997. 
ESFAHANI, H.S.; SALEHI-ISFAHANI, D. Effort observability and worker productivity: towards an explanation of economic dualism. The Economic Journal, vol. 99, n.397, p. 818836, 1989. Disponível em http://www.jstor.org. Acesso em: 3 out. 2005.

FARRELL, D. The hidden dangers of the informal economy. The McKinsey Quarterly, n.3, 2004. Disponível em: http://www.mckinsey.com/mgi/publications/informaleconomy.asp. Acesso em: 6 set. 2006.

FERNANDES, R. Desigualdade salarial: aspectos teóricos. In: COURSEUIL, C. H. (Org.). Estrutura salarial: aspectos conceituais e novos resultados para o Brasil. Rio de Janeiro: IPEA, 2002. p.1-50.

FERNANDES, R.; PAZELLO, E. T.; FELÍCIO, F. A importância da estrutura familiar e do engajamento no mercado de trabalho na determinação da pobreza no Brasil. Pesquisa e planejamento econômico (PPE), Rio de Janeiro, v.32, n.2, p.233-50, ago. 2002.

FRIEDMAN, E.; JOHNSON, S.; KAUFMANN, D.; ZOIDO-LOBATON, P. Dodging the grabbing hand: the deteminants of unofficial activity in 69 countries. Journal of Public Economics, Amsterdam, v.76, p. 459-493, 2000. Disponível em: http://www.elsevier.com/locate/econbase. Acesso em: 8 fev. 2006

FUGAZZA, M; JACQUES, J. F. Labor market institutions, taxation and the underground economy. Journal of Public Economics, Amsterdam, v. 88, p.395-418, 2003. Disponível em http://www.elsevier.com/locate/econbase. Acesso em:22 mar. 2006

GËRXHANI, K. Informal Sector in Developed and less Developed Countries: A Literature Survey. Tinbergen Institute Discussion Papers from Tinbergen Institute 1999 (aceito para publicação no Public Choice). Disponível em http://www.tinbergen.nl/discussionpapers/99083.pdf $>$ Acesso em: 23 out. 2005.

GOLDBERG, P. K; PAVCNIK, N. The response of the informal sector to trade liberalization. Journal of Development Economics, v. 72, p.463-96, 2003.

HART, K. Informal income opportunities and urban employment in Ghana. Journal of Modern African Studies, v.11, p.61-89, 1973. Disponível em: http://links.jstore.org/sici? sici=0022278X\%28197303\%2911\%3A13C61\%3AIIOAUE\%3E20 CO\%3B2X Acesso em: $21 \mathrm{dez} .2006$.

HENLEY, A.; ARABSHEIBANI, G. R.; CARNEIRO, F. G. On defining and measuring the informal sector. World Bank Policy Research Working Paper, v. 3866, mar. 2006. Disponível em: http://ideas.repec.org/p/wbk/wbrwps/3866.html Acesso em: 4 mar. 2006.

IHRIG, J; MOE, K. Tax policies and informal employment: the asian experience. Asian Economic Journal, vol.15, n.4, 2001. Disponível em http://www.blackwell synergy.com/links/doi/10.1111/1467-8381.00150. Acesso em: 
JOHNSON, S; KAUFMANN, D.; ZOIDO-LOBATÓN. Regulatory discretion and the unofficial economy. American Economic Review, vol.88, n.2, 1998, p. 387-92. Disponível em: http://www.jstor.org/view/00028282/ap000002/00a00730/0

KELEJIAN, H. Two-stage least squares and econometric systems linear in parameters but nonlinear in the endogenous variables. Journal of American Statistical Association, New York, n.66, p.33-50, 1978.

KON, A. Diversidade nas condições de informalidade do trabalho brasileiro. Disponível em < http: ideas.repec.org/p/anp/en2004/156.html>. Acesso em 19 dez. 2005.

LEMIEUX, T; FORTIN, B; FRÉCHETTE, P. The effect of taxes on labor supply in the underground economy. The American Economic Review, v. 84, n.1, p.231-254, 1994. Disponível em http://www.jstor.org/view/00028282/di976323/97p00147/0. Acesso em: 22 maio 2006.

LOAYZA, N. The economics of the informal sector: a simple model and some empirical

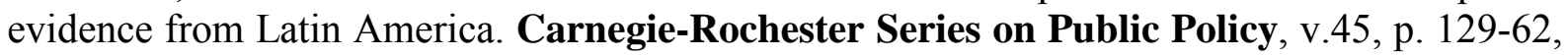
1996. http://ideas.repec.org/p/wbk/wbrwps/1727.htm1 Acesso em: 18 nov. 2005.

LOAYZA, N. V.; OVIEDO, A. M.; SERVEN, L. The impact of regulation on growth and informality. Cross-country evidence. The World Bank Policy Research Working Paper Series, v. 3623, 2005. Disponível em

http://papers.ssrn.com/sol3/papers.cfm?abstract $\mathrm{id}=755087$. Acesso em: 18 nov. 2005.

MALONEY, W. F. Informality revisited. World Development. vol.32, n.7, p.1159-1178, 2004. Disponível em <http:/www.elsevier.com/locate/worlddev . Acesso em: 2 set. 2005.

MONTEIRO, J. C. M.; ASSUNÇÃO, J. J. O impacto da lei do SIMPLES sobre a formalização das firmas, 2004. Disponível em http://www.sbe.org.br/ebe26/048.pdf . Acesso em: 13 jul. 2005.

MONTEIRO, J. C. M. Microempresas no Brasil: informalidade e contratos de trabalho. Rio de Janeiro, 2004, 54f. Dissertação (Mestrado) - Departamento de Economia, Pontifícia Universidade Católica do Rio de Janeiro, Rio de Janeiro, 2004.

NERI, M. Emprego e negócios informais: subsídios para políticas. Rio de Janeiro. Boletim de Mercado de Trabalho. Conjuntura e Análise,n. 14. IPEA, p.5-8, 2000.

Decent work and the informal sector in Brazil. Ensaios Econômicos da EPGE, $n$.

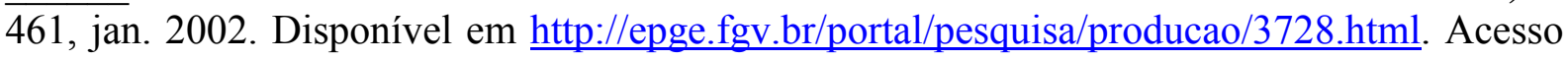
em: 18 abr. 2006.

Análise dos negócios nanicos a partir da pesquisa Economia Informal Urbana -

ECINF. SEBRAE, 2005. (Texto para discussão, n.1). Disponível em 
http://www.sebrae.com.br/br/aprendasebrae/arq aprendasebrae/texto discussao 01.pdf

Acesso em: 18 abr. 2006.

OLIVEIRA, C. W. A.; GUIMARÃES NETO, L. Emprego organizado e regiões nos anos 90: quem perdeu mais? Estudos econômicos, São Paulo, n.27, p. 37-64, 1997.

PORTES, A.; SCHAUFFLER, R. Competing perspectives on the Latin American informal sector. Population and development Review, v.19, n.1, p 33-60, 1993. Disponível em http://www.jstor.org. Acesso em: 23 jan. 2006.

RAMOS, L. A evolução da informalidade no Brasil metropolitano: 1991-2001.IPEA, 2002 (Texto para Discussão, 914). Disponível em <http.www.ipea.gov.br . Acesso em 8 ago. 2005.

RIBEIRO, R. N; BUGARIN, M. N. S. Fatores determinantes e evolução da economia submersa no Brasil. Estudos Econômicos, v.33, n.2, 2003. Disponível em: $<$ http:www.unb.br/face/eco/mirta/trabalhos/ Econ_Submersa_Estudos_Economicos_rev.pdf $>$. Acesso em: 6 jan. 2006.

SAMPIERI, R. H.; COLLADO, C. F.; LUCIO, P. B. Metodologia de la investigación. México: Pan-americana Formas e Impressos S.A., 1994.

SCHNEIDER, F; ENSTE, D. H. Shadow Economies: size, causes, and consequences. Journal of Economic Literature, v.38, p.77-114, mar. 2000. Disponível em: http://www.jstor.org/view/00220515/di010574/01p00812/0 Acesso em: 6 set. 2005.

SCORZAFAVE, L. G; MENEZES-FILHO, N. A. Participação feminina no mercado de trabalho brasileiro: evolução e determinantes. Pesquisa e planejamento econômico, Rio de Janeiro, v.31, n.3, dez. 2001.

THEODORO, M. O Estado e os diferentes enfoques sobre o informal. Brasília: IPEA, nov. 2002. (Texto para Discussão n. 919)

THOMAS, J. Decent work in the informal sector: Latin America. Regional and country papers. International Labour Conference (ILC), 2002. Disponível em: http://www.ilo.org/infeco, Acesso em: 18fev. 2006.

ULYSSEA, G. Informalidade no mercado de trabalho brasileiro: uma resenha da literatura. Rio de Janeiro: IPEA, 2005a. (Texto para Discussão, v.1070).

Instituições e a informalidade no mercado de trabalho. Rio de Janeiro: IPEA, 2005b. (Texto para Discussão, v. 1096)

WOOLDRIDGE, J. M. Econometric analiysis of cross section and panel data. Massachusetts. The MIT Press, 2002. 


\section{APÊNDICE A}

\section{APÊNDICE A1 - Atividades abrangidas pelo SIMPLES - Grupo de tratamento}

\begin{tabular}{|c|c|c|c|}
\hline $\begin{array}{l}\text { Código da } \\
\text { atividade }\end{array}$ & Atividade & Freqüência & Percentual \\
\hline 13001 & Extração de minérios de metais preciosos & 0 & 0 \\
\hline 13002 & $\begin{array}{l}\text { Extração de minerais metálicos - exclusive metais preciosos e } \\
\text { radioativos }\end{array}$ & 0 & 0 \\
\hline 14001 & Extração de pedras e outros materiais para construção & 411 & 0,04 \\
\hline 14002 & Extração de pedras preciosas e semi-preciosas & 0 & 0 \\
\hline 15010 & Abate e preparação de carne e pescado & 262 & 0,03 \\
\hline 15021 & Produção de conservas de frutas, legumes e outros vegetais & 0 & 0 \\
\hline 15022 & Produção de gorduras e óleos vegetais & 0 & 0 \\
\hline 15030 & Fabricação de produtos do laticínio & 1642 & 0,16 \\
\hline 15043 & Fabricação de outros produtos alimentícios & 24913 & 2,39 \\
\hline 17001 & Beneficiamento de fibras, fiação e tecelagem & 352 & 0,03 \\
\hline 17002 & Fabricação de artefatos têxteis a partir de tecidos - exclusive vestuário & 6142 & 0,59 \\
\hline 18001 & Confecção de artigos do vestuário e acessórios - exclusive sob medida & 30259 & 2,91 \\
\hline 18002 & Confecção sob medida de artigos do vestuário e acessórios & 14443 & 1,39 \\
\hline 19011 & Curtimento e outras preparações de couro & 284 & 0,03 \\
\hline 19012 & Fabricação de artefatos de couro & 11193 & 1,08 \\
\hline 19020 & Fabricação de calçados & 13083 & 1,26 \\
\hline 20000 & Fabricação de produtos de madeira & 4983 & 0,48 \\
\hline 21001 & Fabricação de celulose, papel e papelão liso, cartolina e cartão & 0 & 0 \\
\hline 21002 & $\begin{array}{l}\text { Fabricação de papelão corrugado e de embalagens e artefatos de papel } \\
\text { e papelão }\end{array}$ & 166 & 0,02 \\
\hline 22000 & Edição, impressão e reprodução de gravações & 14701 & 1,41 \\
\hline 23020 & Fabricação de produtos do refino do petróleo & 230 & 0,02 \\
\hline 24020 & Fabricação de produtos farmacêuticos & 401 & 0,04 \\
\hline 24030 & Fabricação de sabões, detergentes, produtos de limpeza e perfumaria & 294 & 0,03 \\
\hline 24090 & Fabricação de produtos químicos diversos & 451 & 0,04 \\
\hline 25010 & Fabricação de produtos de borracha & 1824 & 0,18 \\
\hline 25020 & Fabricação de produtos de plástico & 0 & 0 \\
\hline 26010 & Fabricação de vidro e produtos de vidro & 0 & 0 \\
\hline 26091 & Fabricação de produtos cerâmicos & 4458 & 0,43 \\
\hline 26092 & Fabricação de produtos diversos de minerais não-metálicos & 2098 & 0,20 \\
\hline 27001 & Fabricação de produtos siderúrgicos & 0 & 0 \\
\hline 27002 & Metalurgia dos metais não-ferrosos & 279 & 0,03 \\
\hline 27003 & Fundição & 83 & 0,01 \\
\hline 28001 & Fabricação de produtos de metal - exclusive máquinas e equipamentos & 17918 & 1,72 \\
\hline 28002 & $\begin{array}{l}\text { Forjaria, estamparia, metalurgia do pó e serviços de tratamento de } \\
\text { metais }\end{array}$ & 2452 & 0,24 \\
\hline 29001 & Fabricação de máquinas e equipamentos - exclusive eletrodomésticos & 7967 & 0,77 \\
\hline 29002 & Fabricação de eletrodomésticos & 0 & 0 \\
\hline 30000 & Fabricação de máquinas de escritório e equipamentos de informática & 0 & 0 \\
\hline 31001 & $\begin{array}{l}\text { Fabricação de máquinas, aparelhos e materiais elétricos diversos - } \\
\text { exclusive para veículos }\end{array}$ & 2935 & 0,28 \\
\hline 31002 & Fabricação de material elétrico para veículos & 0 & 0 \\
\hline 32000 & $\begin{array}{l}\text { Fabricação de material eletrônico e de aparelhos e equipamentos de } \\
\text { comunicação }\end{array}$ & 0 & 0 \\
\hline 33001 & Fabricação de aparelhos e equipamentos médico-hospitalares & 574 & 0,06 \\
\hline 33003 & $\begin{array}{l}\text { Fabricação de máquinas, aparelhos e equipamentos de sistemas } \\
\text { eletrônicos dedicados a automação industrial e controle do processo } \\
\text { produtivo }\end{array}$ & 2344 & 0,23 \\
\hline 33004 & $\begin{array}{l}\text { Fabricação de aparelhos, instrumentos e materiais ópticos, } \\
\text { fotográficos e cinematográficos }\end{array}$ & 0 & 0 \\
\hline 34002 & $\begin{array}{l}\text { Fabricação de cabines, carrocerias, reboques e peças para veículos } \\
\text { automotores }\end{array}$ & 0 & 0 \\
\hline
\end{tabular}




\begin{tabular}{|c|c|c|c|}
\hline $\begin{array}{l}\text { Código da } \\
\text { atividade }\end{array}$ & Atividade & Freqüência & Percentual \\
\hline 35090 & Fabricação de equipamentos de transporte diversos & 1792 & 0,17 \\
\hline 36010 & Fabricação de artigos do mobiliário & 14650 & 1,41 \\
\hline 36090 & Fabricação de produtos diversos & 3561 & 0,34 \\
\hline 37000 & Reciclagem & 0 & 0 \\
\hline 50010 & Comércio de veículos automotores & 3191 & 0,31 \\
\hline 50020 & Serviços de reparação e manutenção de veículos automotores & 59391 & 5,70 \\
\hline 50030 & Comércio de peças e acessórios para veículos automotores & 17259 & 1,66 \\
\hline 50040 & Comércio, manutenção e reparação de motocicletas & 5931 & 0,57 \\
\hline 50050 & Posto de combustíveis & 2173 & 0,21 \\
\hline 53020 & Comércio de produtos agropecuários & 2654 & 0,25 \\
\hline 53030 & Comércio de produtos alimentícios, bebidas e fumo & 69965 & 6,72 \\
\hline 53041 & Comércio de fios têxteis, tecidos, artefatos de tecidos e armarinho & 8763 & 0,84 \\
\hline 53042 & Comércio de artigos do vestuário, complementos e calçados & 40325 & 3,87 \\
\hline 53050 & Comércio de madeira, material de construção, ferragens e ferramentas & 31178 & 2,99 \\
\hline 53061 & Comércio de eletrodomésticos, móveis e outros artigos de residência & 21950 & 2,11 \\
\hline 53062 & Comércio de livros, jornais, revistas e papelaria & 8759 & 0,84 \\
\hline 53063 & $\begin{array}{l}\text { Comércio de produtos farmaceuticos, médicos, ortopédicos, } \\
\text { odontológicos e de cosméticos e perfumaria }\end{array}$ & 12834 & 1,23 \\
\hline 53064 & $\begin{array}{l}\text { Comércio de máquinas, aparelhos e equipamentos - exclusive } \\
\text { eletrodomésticos }\end{array}$ & 8805 & 0,85 \\
\hline 53065 & Comércio de combustiveis - exclusive posto de combustíveis & 5932 & 0,57 \\
\hline 53066 & Comércio de resíduos e sucatas & 10290 & 0,99 \\
\hline 53068 & Comércio de mercadorias em geral - inclusive mercadorias usadas & 36307 & 3,49 \\
\hline 53070 & Supermercado e Hipermercado & 4204 & 0,40 \\
\hline 53080 & $\begin{array}{l}\text { Lojas de departamento e outros comércios não especializados, sem } \\
\text { predominância de produtos alimentícios }\end{array}$ & 8669 & 0,83 \\
\hline 53090 & $\begin{array}{l}\text { Comércio varejista de artigos em geral por catálogo, televisão, internet } \\
\text { e outros meios de comunicação }\end{array}$ & 78 & 0,01 \\
\hline 53101 & $\begin{array}{l}\text { Comércio varejista realizado em postos móveis, instalados em vias } \\
\text { públicas ou em mercados }\end{array}$ & 20684 & 1,99 \\
\hline 53102 & $\begin{array}{l}\text { Outros tipos de comércio varejista, não realizados em lojas - exclusive } \\
\text { feira de artesanato e comércio ambulante }\end{array}$ & 0 & 0 \\
\hline 53112 & Reparação de calçados & 963 & 0,09 \\
\hline 55010 & Alojamento & 4794 & 0,46 \\
\hline 55020 & Ambulantes de alimentação & 6398 & 0,61 \\
\hline 55030 & Outros serviços de alimentação - exclusive ambulantes & 84672 & 8,13 \\
\hline 60031 & Transporte rodoviário de cargas - exclusive de mudanças & 17585 & 1,69 \\
\hline 60032 & Transporte rodoviário de mudanças & 48 & 0,00 \\
\hline 60040 & Transporte rodoviário de passageiros & 17335 & 1,66 \\
\hline 61000 & Transporte aquaviário & 1536 & 0,15 \\
\hline 62000 & Transporte aéreo & 1498 & 0,14 \\
\hline 63021 & Atividades auxiliares aos transportes & 5287 & 0,51 \\
\hline 71010 & Aluguel de veículos & 3625 & 0,35 \\
\hline 71020 & Aluguel de máquinas e equipamentos & 2767 & 0,27 \\
\hline 71030 & Aluguel de objetos pessoais e domésticos & 3862 & 0,37 \\
\hline 92011 & Produção de filmes cinematográficos e fitas de vídeo & 242 & 0,02 \\
\hline 93010 & Lavanderias e tinturarias & 4072 & 0,39 \\
\hline 93020 & Cabeleireiros e outros tratamentos de beleza & 28318 & 2,72 \\
\hline 93092 & Outras atividades de serviços pessoais & 2,255 & 0,22 \\
\hline Total & & 751743 & 72,20 \\
\hline
\end{tabular}

Fonte: (IBGE; ECINF, 2003) - Elaboração própria. 


\section{APÊNDICE A2 - Atividades não abrangidas pelo SIMPLES - Grupo de comparação}

\begin{tabular}{|c|c|c|c|}
\hline $\begin{array}{l}\text { Código da } \\
\text { atividade }\end{array}$ & Atividade & Freqüência & Percentual \\
\hline 02002 & $\begin{array}{l}\text { Atividades de serviços relacionados com a silvicultura e a exploração } \\
\text { florestal }\end{array}$ & 0 & 0 \\
\hline 15041 & Fabricação e refino do açúcar & 0 & 0 \\
\hline 15055 & Fabricação de bebidas & 0 & 0 \\
\hline 16000 & Fabricação de produtos do fumo & 0 & 0 \\
\hline 34003 & $\begin{array}{l}\text { Recondicionamento ou recuperação de motores de veículos } \\
\text { automotores }\end{array}$ & 891 & 0,09 \\
\hline 35010 & Construção e reparação de embarcações & 0 & 0 \\
\hline 35020 & $\begin{array}{l}\text { Construção e montagem de locomotivas, vagões e outros materiais } \\
\text { rodantes }\end{array}$ & 0 & 0 \\
\hline 35030 & Construção, montagem e reparação de aeronaves & 207 & 0,02 \\
\hline 40001 & Produção e distribuição de energia elétrica & 0 & 0 \\
\hline 45001 & Preparação do terreno & 245 & 0,02 \\
\hline 45002 & Construção de edifícios e obras de engenharia civil & 34112 & 3,28 \\
\hline 45003 & Obras de instalações & 8050 & 0,77 \\
\hline 45004 & Obras de acabamento e serviços auxiliares da construção & 34380 & 3,30 \\
\hline 53010 & Representantes comerciais e agentes do comércio & 31337 & 3,01 \\
\hline 53111 & Reparação e manutenção de eletrodomésticos & 4188 & 0,40 \\
\hline 53113 & $\begin{array}{l}\text { Reparação de objetos pessoais e domésticos - exclusive de } \\
\text { eletrodomésticos e calçados }\end{array}$ & 2753 & 0,26 \\
\hline 63010 & Carga e descarga, armazenamento e depósitos & 377 & 0,04 \\
\hline 63022 & Organização do transporte de cargas & 1942 & 0,19 \\
\hline 63030 & Agências de viagens e organizadores de viagens & 3619 & 0,35 \\
\hline 64010 & Atividades de correio & 121 & 0,01 \\
\hline 65000 & Intermediação Financeira & 458 & 0,04 \\
\hline 66000 & Seguros e previdência privada & 273 & 0,03 \\
\hline 67010 & Atividades auxiliares da intermediação financeira & 1680 & 0,16 \\
\hline 67020 & Atividades auxiliares dos seguros e da previdência privada & 1477 & 0,14 \\
\hline 70001 & Atividades imobiliárias - exclusive condomínios prediais & 9455 & 0,91 \\
\hline 70002 & Condomínios prediais & 524 & 0,05 \\
\hline 72010 & $\begin{array}{l}\text { Atividades de informática - exclusive manutenção e reparação de } \\
\text { máquinas de escritório e informática }\end{array}$ & 2464 & 0,24 \\
\hline 72020 & Manutenção de máquinas de escritório e informática & 2111 & 0,20 \\
\hline 73000 & Pesquisa e desenvolvimento & 0 & 0 \\
\hline 74011 & $\begin{array}{l}\text { Atividades jurídicas; de contabilidade; e de pesquisas de mercado e } \\
\text { opinião pública }\end{array}$ & 22193 & 2,13 \\
\hline 74012 & Atividades de assessoria em gestão empresarial & 3180 & 0,31 \\
\hline 74021 & $\begin{array}{l}\text { Serviços de arquitetura e engenharia e de assessoramento técnico } \\
\text { especializado }\end{array}$ & 8266 & 0,79 \\
\hline 74022 & Ensaios de materiais e de produtos; análise de qualidade & 0 & 0 \\
\hline 74030 & Publicidade & 9481 & 0,91 \\
\hline 74040 & Seleção, agenciamento e locação de mão-de-obra & 562 & 0,05 \\
\hline 74050 & Investigação, vigilância e segurança & 1314 & 0,13 \\
\hline 74060 & Limpeza de prédios e domicílios & 1771 & 0,17 \\
\hline 74090 & Outros serviços prestados às empresas & 10208 & 0,98 \\
\hline 75011 & Administração do Estado e da política econômica e social - Federal & 0 & 0 \\
\hline 75012 & Administração do Estado e da política econ. e social - Estadual & 0 & 0 \\
\hline 75013 & Administração do Estado e da política econômica e social - Municipal & 0 & 0 \\
\hline 75014 & Forças Armadas & 0 & 0 \\
\hline 75015 & $\begin{array}{l}\text { Outros serviços coletivos prestados pela administração pública - } \\
\text { Federal }\end{array}$ & 0 & 0 \\
\hline 75016 & $\begin{array}{l}\text { Outros serviços coletivos prestados pela administração pública - } \\
\text { Estadual }\end{array}$ & 0 & 0 \\
\hline 75017 & $\begin{array}{l}\text { Outros serviços coletivos prestados pela administração pública - } \\
\text { Municipal }\end{array}$ & 0 & 0 \\
\hline
\end{tabular}




\begin{tabular}{clcc}
\hline $\begin{array}{c}\text { Código da } \\
\text { atividade }\end{array}$ & \multicolumn{1}{c}{ Atividade } & Freqüência & Percentual \\
\hline 75020 & Seguridade social & 0 & 0 \\
80011 & Educação regular, supletiva e especial pública & 0 & 0 \\
80012 & Educação regular, supletiva e especial particular & 14848 & 1,43 \\
80090 & Outras atividades de ensino & 14001 & 1,34 \\
85012 & Saúde particular & 40431 & 3,88 \\
85013 & Outras atividades de saúde & 205 & 0,02 \\
85020 & Serviços veterinários & 663 & 0,06 \\
85030 & Serviços sociais & 17 & 0,00 \\
90000 & Limpeza urbana e esgoto; e atividades conexas & 355 & 0,03 \\
91010 & Atividades de organizações sindicais & 0 & 0 \\
92013 & Radiodifusão & 684 & 0,07 \\
92014 & Televisão & 55 & 0,01 \\
92015 & Outras atividades artísticas e de espetáculos & 7759 & 0,75 \\
92020 & Agência de notícias & 18 & 0,00 \\
92030 & Bibliotecas, arquivos, museus e outras atividades culturais & 0 & 0 \\
92040 & Atividades desportivas e outras relacionadas ao lazer & 12292 & 1,18 \\
93030 & Atividades funerárias & 35 & 0,00 \\
93091 & Atividades de manutenção do fisico corporal & 426 & 0,04 \\
95000 & Serviços domésticos & 0 & 0 \\
99000 & Organismos internacionais e outras instituições extraterritoriais & 0 & 0 \\
\hline Total & & $\mathbf{2 8 9 4 2 8}$ & $\mathbf{2 7 , 8 0}$ \\
\hline
\end{tabular}

Fonte: (IBGE; ECINF, 2003) - Elaboração própria.

\section{APÊNDICE A3 - Atividades excluídas da análise}

\begin{tabular}{cl}
\hline Código da atividade & \multicolumn{1}{c}{ Descrição da atividade } \\
\hline 15055 & Fabricação de bebidas \\
64020 & Telecomunicações \\
91091 & Atividades de organizações religiosas e filosóficas \\
92030 & Bibliotecas, arquivos, museus e outras atividades culturais \\
00000 & Atividades mal definidas, não declaradas e outras não compreendidas \\
& nas demais subclasses \\
\hline
\end{tabular}

Fonte: (IBGE; ECINF, 2003) - Elaboração própria. 


\section{APÊNDICE B}

APÊNDICE B1 - Sumário detalhado dos valores ajustados para resultado da regressão por MQ2E (equação reduzida) - amostra total sem filtro - antes de adequá-los no intervalo entre $(0,1)$

\begin{tabular}{|c|c|c|c|c|}
\hline & Percentis & Menor & & \\
\hline $1 \%$ & $-0,0415$ & $-0,2206$ & & \\
\hline $5 \%$ & 0,1465 & $-0,1917$ & & \\
\hline $10 \%$ & 0,2420 & $-0,1796$ & Obs & 3391 \\
\hline $25 \%$ & 0,4504 & $-0,1775$ & Sum of Wgt, & 3391 \\
\hline & & & & \\
\hline $50 \%$ & 0,6650 & & Média & 0,6336 \\
\hline & & Maior & Desv. Padrão & 0,2731 \\
\hline $75 \%$ & 0,8447 & 1,2857 & & 0,0746 \\
\hline $90 \%$ & 0,9607 & 1,3262 & Variância & $-0,4423$ \\
\hline $95 \%$ & 1,0233 & 1,3340 & Skewness & 2,7061 \\
\hline $99 \%$ & 1,1349 & 1,4129 & Kurtosis & \\
\hline
\end{tabular}

Fonte: Elaboração própria

APÊNDICE B2 - Sumário detalhado dos valores ajustados para resultado da regressão por MQ2E (equação reduzida) - amostra total sem filtro - depois de adequá-los no intervalo entre $(0,1)$

\begin{tabular}{|c|c|c|c|c|}
\hline & Percentis & Menor & & \\
\hline $1 \%$ & 0 & 0 & & \\
\hline $5 \%$ & 0,1465 & 0 & & \\
\hline $10 \%$ & 0,2420 & 0 & Obs & 3391 \\
\hline $25 \%$ & 0,4504 & 0 & Sum of Wgt, & 3391 \\
\hline & & & & \\
\hline $50 \%$ & 0,6650 & & Média & 0,6300 \\
\hline & & Maior & Desv. Padrão & 0,2621 \\
\hline $75 \%$ & 0,8447 & 1 & & 0,0687 \\
\hline $90 \%$ & 0,9607 & 1 & Variância & $-0,5209$ \\
\hline $95 \%$ & 1 & 1 & Skewness & 2,4617 \\
\hline $99 \%$ & 1 & 1 & Kurtosis & 2 \\
\hline
\end{tabular}

* Houve mudança em 229 valores que eram acima de 1 e diferente de missing e mudança em 60 valores abaixo de 0 .

Fonte: Elaboração própria 
APÊNDICE B3 - Sumário detalhado dos valores ajustados para resultado da regressão por MQ2E (equação reduzida) - MQ2E (equação reduzida) filtrado para "ano95" e "ano96" antes de adequá-los no intervalo entre $(0,1)$

\begin{tabular}{|c|c|c|c|c|}
\hline & Percentis & Menor & & \\
\hline $1 \%$ & 0,0018 & $-0,1627$ & & \\
\hline $5 \%$ & 0,1503 & $-0,1508$ & & \\
\hline $10 \%$ & 0,2405 & $-0,0110$ & Obs & 489 \\
\hline $25 \%$ & 0,4683 & 0,0018 & Sum of Wgt, & 489 \\
\hline & & & & \\
\hline $50 \%$ & 0,6830 & & Média & 0,6735 \\
\hline & & Maior & Desv. Padrão & 0,2993 \\
\hline $75 \%$ & 0,8858 & 1,3165 & & \\
\hline $90 \%$ & 1,0479 & 1,3715 & Variância & 0,0896 \\
\hline $95 \%$ & 1,1602 & 1,4232 & Skewness & $-0,1944$ \\
\hline $99 \%$ & 1,3080 & 1,4303 & Kurtosis & 2,5452 \\
\hline
\end{tabular}

Fonte: Elaboração própria

APÊNDICE B4 - Sumário detalhado dos valores ajustados para resultado da regressão por MQ2E (equação reduzida) - MQ2E (equação reduzida) filtrado para "ano95" e "ano96" depois de adequá-los no intervalo entre $(0,1)$

\begin{tabular}{|c|c|c|c|c|}
\hline & Percentis & Menor & & \\
\hline $1 \%$ & 0,0018 & 0 & & \\
\hline $5 \%$ & 0,1503 & 0 & & \\
\hline $10 \%$ & 0,2405 & 0 & Obs & 489 \\
\hline $25 \%$ & 0,4683 & 0,0017766 &, Sum of Wgt & 489 \\
\hline & & & & \\
\hline $50 \%$ & 0,6830 & & Média & 0,6568 \\
\hline & & Maior & Desv. Padrão & 0,2712 \\
\hline $75 \%$ & 0,8858 & 1 & & \\
\hline $90 \%$ & 1 & 1 & Variância & 0,0736 \\
\hline $95 \%$ & 1 & 1 & Skewness & $-0,5070$ \\
\hline $99 \%$ & 1 & 1 & Kurtosis & 2,3263 \\
\hline
\end{tabular}

* Houve mudança em 69 valores que eram acima de 1 e diferente de missing e mudança em 3 valores abaixo de 0 .

Fonte: Elaboração própria 
SILVA, R. M. H. Micro e pequenas empresas formais afetam o fato de seus empregados serem formais? Um estudo utilizando o SIMPLES como uma variável instrumental. 2007. 82f. Dissertação (Mestrado) - Faculdade de Economia, Administração e Contabilidade de Ribeirão Preto, Departamento de Economia, Universidade de São Paulo, Ribeirão Preto.

\section{ERRATA}

$\begin{array}{lccc}\text { Folha } & \text { Linha } & \text { Onde se lê } & \text { Leia-se } \\ \mathbf{5 8} & \mathbf{8} & \text { "educ6p" } & \text { "educ5p" } \\ \mathbf{7 2} & \mathbf{3} & \mathbf{5 \%} & \mathbf{1 0 \%}\end{array}$

